\title{
Indoor Air Quality Commissioning of a New Office Building
}

W. Stuart Dols

Andrew K. Persily

Steven J. Nabinger

Building and Fire Research Laboratory

Gaithersburg, MD 20899

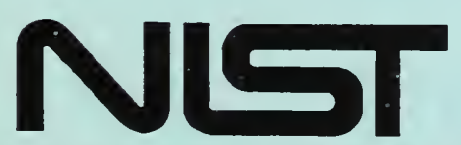

United States Department of Commerce

Technology Administration

National Institute of Standards and Technology

QC

100

.056

N0. 5586

1995 



\section{Indoor Air Quality Commissioning}

of a New Office Building

W. Stuart Dols

Andrew K. Persily

Steven J. Nabinger

January 1995

Building and Fire Research Laboratory

National Institute of Standards and Technology

Gaithersburg, MD 20899

\section{U. S. Department of Commerce}

Ronald H. Brown, Secretary

Mary L. Good, Under Secretary for Technology

National Institute of Standards and Technology

Arati Prabhakar, Director
Prepared for:

U.S. Nuclear Regulatory Commission

Office of Consolidation

Rockville, Maryland 



\section{ABSTRACT}

New buildings can have an increased potential for indoor air quality problems due to new building materials and deficiencies in mechanical ventilation system performance during construction and initial occupancy. In order to decrease the potential for such problems, an indoor air quality commissioning program was developed and implemented by the National Institute of Standards and Technology in a new office building for the United States Nuclear Regulatory Commission. This indoor air quality commissioning effort consisted of three tasks: (1) evaluate the mechanical ventilation system design; (2) develop a set of environmental parameters and associated reference values to be used in evaluating the building indoor air quality; and, (3) measure these environmental parameters in this building and compare them with the reference values developed in Task 2 . The evaluation of the mechanical ventilation system design was based on the recommendations of the 1987 BOCA mechanical code and ASHRAE Standard 62-1989. The design evaluation showed that the system ventilation rates were consistent with the recommendations of both documents. The environmental parameters identified in Task 2 address ventilation system performance, indoor pollutant levels, and thermal comfort. The reference values for these parameters were based on available standards and guidelines as well as on the results of previous indoor air quality research. In Task 3, these environmental parameters were measured in three phases of building construction: after completion of interior build-out; after the installation of the systems furniture; and roughly one month after occupancy. The measured values were within the project reference values with only a few exceptions, and these exceptions were usually attributed to a correctable circumstance.

Key Words: building performance, commissioning, indoor air quality, office building, ventilation 



\section{TABLE OF CONTENTS}

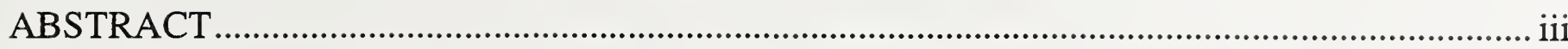

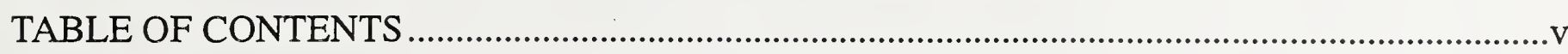

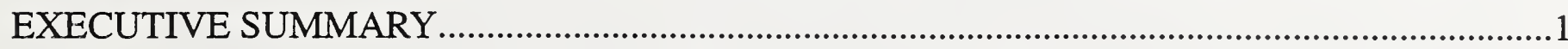

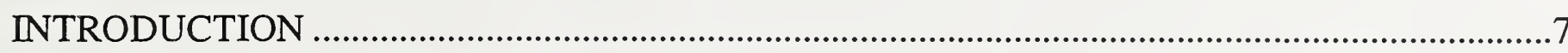

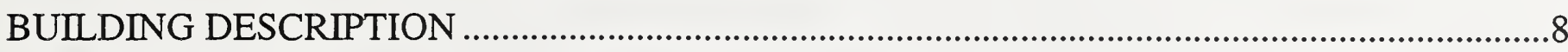

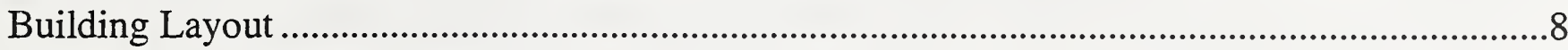

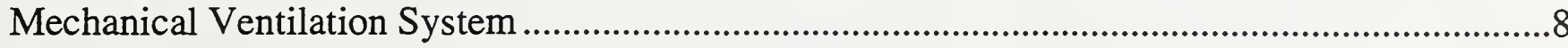

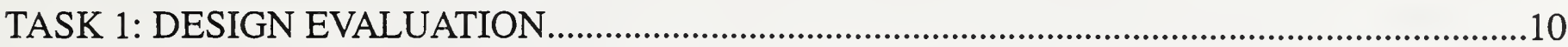

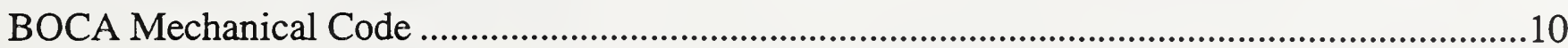

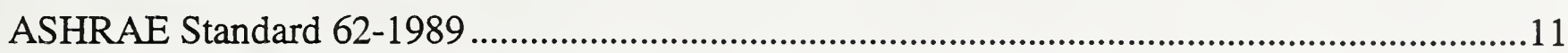

Comparison of Ventilation System Design to BOCA and ASHRAE......................................11

TASK 2: INDOOR ENVIRONMENTAL PARAMETERS ........................................................15

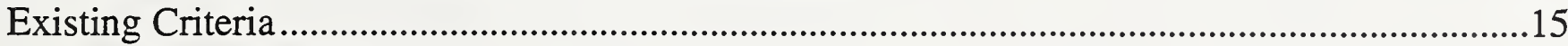

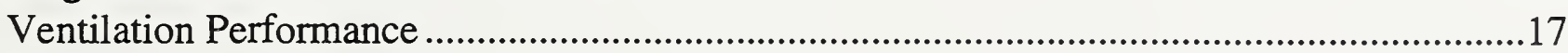

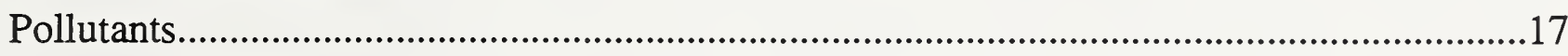

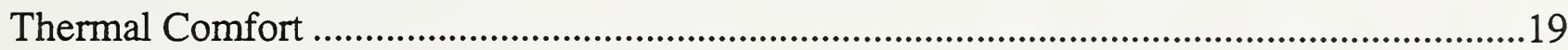

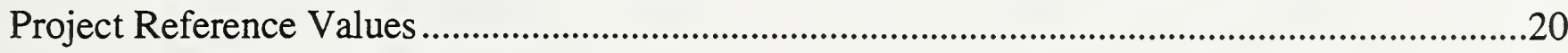

Ventilation Performance ......................................................................................20

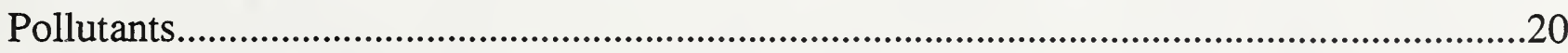

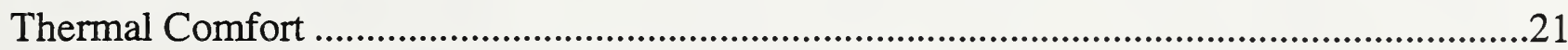

TASK 3: INDOOR ENVIRONMENTAL MEASUREMENTS .................................................23

Construction and IAQ Test Schedule .........................................................................23

Measurement Equipment and Techniques .......................................................................26

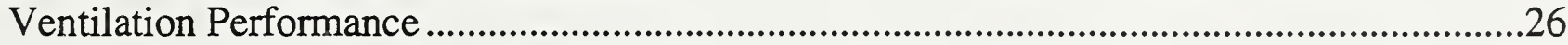

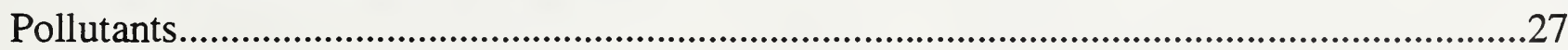

Thermal Comfort ....................................................................................................28

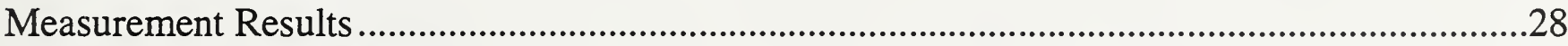

Outdoor Airflow Rate ................................................................................................28

Pressure Relationships between Zones ..........................................................................30

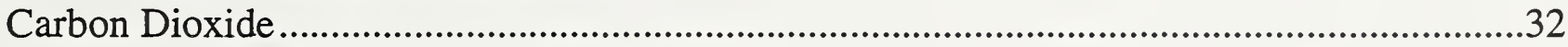

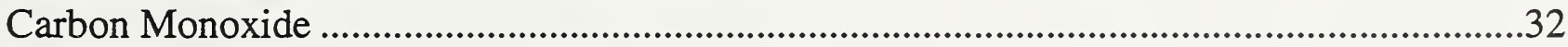

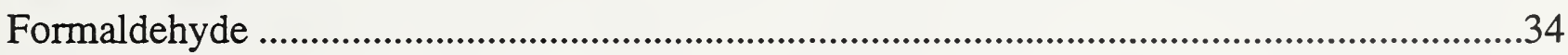

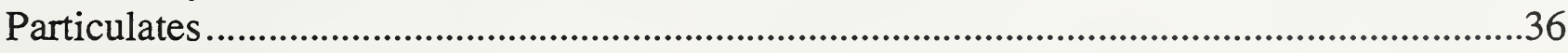

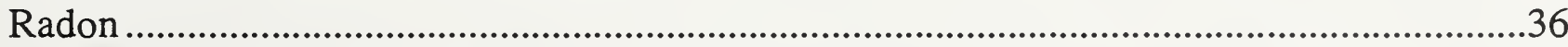

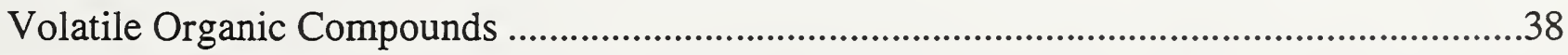

Thermal Comfort ....................................................................................................41

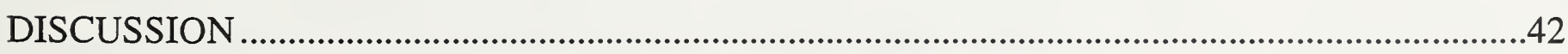

Implementing an IAQ Commissioning Program During Construction ......................................42

Benefits of the NRC IAQ Commissioning Program...........................................................43

Recommendations........................................................................................................44

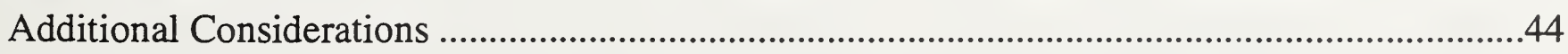

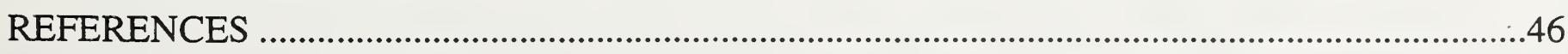

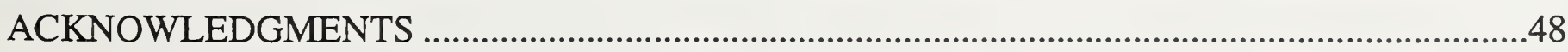





\section{EXECUTIVE SUMMARY}

\section{Introduction}

Building commissioning generally refers to the process of verifying that building mechanical systems are operating as designed. However, commissioning does not always include the verification of an "acceptable" indoor environment for the building occupants, including factors related to indoor air quality (IAQ). In light of growing concern about indoor air quality, IAQ commissioning could become an important part of building commissioning programs. A well-defined and properly-implemented IAQ commissioning program could help provide a healthy and comfortable environment for the building occupants and help to reduce other problems related to building operation. However, there are currently no standard IAQ commissioning protocols.

In order to identify and understand the issues involved in implementing such a program, an IAQ commissioning program was developed and applied to the new NRC office building in Rockville Maryland. This commissioning program is not presented as a candidate for a standardized protocol for IAQ commissioning. Instead, it was intended to provide experience and insight that will assist in the development of future IAQ commissioning protocols. The program described in this report consisted of three tasks: (1) evaluate the mechanical ventilation system design from an IAQ perspective; (2) develop a set of environmental performance parameters and associated reference values that will be used to evaluate IAQ in the building; and, (3) measure these environmental parameters in the building and compare them with the reference values developed in Task 2.

\section{Task 1: Design Evaluation}

The purpose of Task 1 was to compare those features of the building design that pertain to IAQ to relevant building codes and IAQ guidelines. These comparisons were made for outdoor air intake rates and pressure relationships between building zones. The design outdoor air intake rates of the mechanical ventilation system were compared to both the BOCA Mechanical Code, upon which the ventilation system design was based, and ASHRAE Standard 62-1989<Table 2 on page 12>. The design outdoor airflow rates conform with the BOCA Code and in some cases exceed the BOCA requirements. The design outdoor air intake rates are slightly below the ASHRAE recommendations in several zones and well above ASHRAE recommendations in other zones. However, the system is capable of providing outdoor airflow rates that would comply with ASHRAE Standard 62-1989 to all zones of the building.

\section{Task 2: Indoor Environmental Parameters}

Task 2 consisted of the development of a set of parameters to characterize the indoor environment in the building. The values measured in this building were compared to a set of reference values. Ideally, these parameters and the associated reference values would be based on existing standards. However, in most cases there are no IAQ standards for office buildings; therefore, the reference values $<$ Table 5 on page $20>$ were based on other guidelines and the results of previous IAQ research efforts $<$ Table 4 on page 16>. The reference values do not strictly define an acceptable indoor environment, but are meant to provide an indication of the acceptability of the environment based on the limited information that is available, and to identify the potential for situations of 
concern in the building. Three categories of indoor environmental parameters were measured in the building: ventilation, pollutants, and thermal comfort. The following is a list of these parameters.

\begin{tabular}{c} 
Ventilation Performance \\
\hline Outdoor Airflow Rate \\
Pressure Relationship \\
between Zones
\end{tabular}

Pollutants
Carbon Dioxide
Carbon Monoxide
Formaldehyde
Particulates
Radon
Volatile Organic Compounds

\author{
Thermal Comfort \\ Temperature \\ Relative Humidity \\ Operative Temperature
}

\section{Task 3: Indoor Environmental Monitoring}

IAQ monitoring was performed in three phases of building construction: (1) Interior build-out complete, (2) System furniture installed, and (3) Approximately one month after occupancy. The results of these measurements are summarized here.

\section{Outdoor Airflow Rate}

During occupancy (Phase 3), the outdoor air intake rate per person delivered to each of the eleven zones was at or above ASHRAE 62-1989 recommendations with the exception of the sixth floor and the auditorium <Table 8 on page 29>. The outdoor airflow rate to the sixth floor was low because an outdoor air intake damper serving this floor was broken during Phase 3. An outdoor air damper serving one of the fifth floor mechanical rooms was also broken, causing outdoor air intake rates to the fifth floor to be below design levels, but the outdoor air intake rate was still above the ASHRAE guideline of $10 \mathrm{~L} / \mathrm{s}(20 \mathrm{cfm})$ per person for offices. The results of the outdoor delivery rates measured during all three phases are presented along with the design values in Table 7 on page 29.

\section{Pressure Relationships between Zones}

All eleven zones were positively pressurized relative to the stair and elevator shafts. Therefore, a pollutant source in one zone would have minimal (if any) impact on other zones. It appeared that the garage exhaust fans were drawing air from the zones through the stair and elevator shafts. The results of the pressure relationship tests are summarized in a schematic elevation of the building $<$ Figure 2 on page $31>$.

\section{Carbon Dioxide}

During Phase 3 (after building occupancy), all of the measured carbon dioxide levels were below the project reference value of 1000 parts per million (ppm). The only exception was on the sixth floor in the area served by the air handler with a broken outdoor air intake damper. The maximum carbon dioxide concentration measured in this zone was slightly greater than $1000 \mathrm{ppm}$. The results of the carbon dioxide concentrations are presented in Table 9 on page 32 . 


\section{Carbon Monoxide}

All interior concentrations were below $2 \mathrm{ppm}$, which is well below the project reference value of $10 \mathrm{ppm}$. Based on approximately two weeks of automated carbon monoxide data collection, there appeared to be no effect of elevated carbon monoxide levels in the garage on the levels of carbon monoxide in the daycare center as depicted in Figure 3 on page 33.

\section{Formaldehyde}

Most concentrations were at or below the reference value of $0.05 \mathrm{ppm}$; outdoor levels were sometimes as high as $0.04 \mathrm{ppm}$. During Phase 1 all levels were at or below $0.05 \mathrm{ppm}$. During Phase 2 , the daycare center, auditorium, second floor Library and Conference room exhibited slightly higher levels. During Phase 3, concentrations in the daycare center were at the reference value, and those in the third floor hearing room were approximately $0.10 \mathrm{ppm}$. While the reasons for these slightly elevated levels are not certain, both the hearing room and the daycare center contain a fairly high loading of pressed-wood products that could be a source of formaldehyde. The results of all of the measured formaldehyde concentrations are presented in Table 10 on page 35.

\section{Particulates}

The measured concentrations of particles with aerodynamic diameters of 10 micrometers $(\mu \mathrm{m})$ or less (PM10) were below $50 \mu \mathrm{g} / \mathrm{m}^{3}$ which is well below the project reference value of $150 \mu \mathrm{g} / \mathrm{m}^{3}$. Elevated levels were recorded on the fourth floor during Phase 1 due to smoke generated by welding. The results of the particulate measurements are presented in Table 11 on page 36.

\section{$\underline{\text { Radon }}$}

All measured concentrations of radon were approximately 1 picocurie per liter $(\mathrm{pCi} / \mathrm{L})$ or less, which is well below the reference value of $4 \mathrm{pCi} / \mathrm{L}$. The results of all of the radon measurements are presented in Table 12 on page 37.

\section{Total Volatile Organic Compounds}

The levels of total volatile organic compounds (TVOC) were well below the project reference value of $1000 \mu \mathrm{g} / \mathrm{m}^{3}<$ Table 13 on page 38>. Only one measurement exceeded the reference value, and that corresponded to the episode of elevated particulate levels on the fourth floor when welding was taking place. During Phase 3, the TVOC levels were all below $300 \mu \mathrm{g} / \mathrm{m}^{3}$. Analysis of the TVOC source strength indicated that the source strength decreased steadily after the base building was complete, even though the systems furniture was installed and the building was occupied $<$ Figure 4 on page $40>$.

\section{Thermal Comfort}

After the building was occupied, thermal comfort was evaluated during August and September by calculating the predicted percent dissatisfied (PPD) from the measured thermal comfort parameters. PPD is an indicator of the percentage of people that will be dissatisfied for a given set of thermal comfort conditions. Based on the assumptions of slightly active office workers wearing summer clothing, all eleven zones had PPD values that were less than the project criteria of $10 \%$. This result indicates acceptable thermal comfort during the cooling season. The results of the thermal comfort measurements are presented in Table 14 on page 41. 


\section{Lessons Learned and Recommendations}

In addition to providing IAQ performance data in a new office building, the implementation of this IAQ commissioning program revealed several issues that could be helpful in planning and carrying out future commissioning efforts. These issues are discussed in this section and can be categorized as follows: (1) Logistics and jurisdiction, (2) Impact of construction activities, and (3) Equipment and controls problems. The IAQ commissioning efforts in the NRC building also resulted in some unexpected benefits that are described in this section. Finally, based on the experiences in this building, several recommendations are proposed for future IAQ commissioning efforts.

Logistics and jurisdiction issues are related to the fact that the construction of a new building is a complex process involving many people, and that the responsibility for the building and its systems change hands during the construction process. Given the various groups involved in the design and construction of the building and administering the IAQ commissioning program, it is inevitable that some logistical and jurisdictional issues arise. These issues include access to the building by the IAQ commissioners, a lack of familiarity with the HVAC systems on the part of those operating the mechanical systems, responsibility for utility costs associated with system operation schedules required for commissioning, responsibility for repair of system defects, ability of the commissioning staff to obtain up-to-date system design information and information on the construction schedule, and notification of the IAQ commissioners of construction related to change orders.

In implementing the IAQ commissioning program in this building, several issues arose related to the impact of construction activities. The process of constructing a commercial building usually involves unanticipated changes and problems that result in unscheduled construction activities and the need to modify completed spaces. An IAQ test period was included in the construction schedule for each zone during which no construction activities were to take place. However, some last-minute construction occurred during these measurement periods. Several of these activities interfered with and delayed the IAQ testing. However, most of these delays occurred in the early phases of Task 3 and were not a factor once the building was ready for occupancy.

Equipment and controls problems with the HVAC system are not unexpected during the construction and early-occupancy phases of a building, and the identification of these problems is a major benefit of commissioning. However, these problems can interfere with IAQ commissioning.

In addition to increasing the likelihood of providing an indoor environment in the NRC building that is acceptable in terms of occupant health and comfort, there were other benefits to this IAQ commissioning program. The process of conducting the tests revealed defects with the HVAC system that may not have been identified until later in the construction process or perhaps well into building occupancy. Another benefit of the IAQ commissioning was the ability to address specific issues of concern that arose during construction and early occupancy based on the building layout, specific pollutant sources, and occupant concerns. For example, occupant concerns were raised regarding the possibility of motor vehicle exhaust entering the daycare center from the adjacent parking garage. Even though this was not part of the original IAQ commissioning plan, an automated carbon monoxide monitoring system was installed to monitor carbon monoxide levels in the daycare center and garage. 
Based on the results of the commissioning effort in the NRC building, several recommendations can be made for the planning and implementation of future IAQ commissioning programs. The first recommendation is to start planning the commissioning effort as early as possible, well before the design of the building. The need for an early commitment is true for all building commissioning, not just for indoor air quality commissioning. It is critical that the commitment to commissioning the building is made before the building is designed by defining the responsibilities of the various individuals and organizations involved in the process. ASHRAE Guideline 1 [1] describes the steps in this process for commissioning HVAC systems.

The pre-design commissioning activities should include identifying the logistical needs of the IAQ commissioners in terms of building access, parking, telephones, and the storage of test equipment. The manner in which the ventilation system is to be operated at various stages of building construction and IAQ testing must also be identified, as well as those responsible for operating the ventilation system throughout the construction process. Particular attention must be given to these logistical details at times of transition, for example when the contractors responsible for the base-building construction complete their responsibilities and the next phase of construction begins.

Even though the building construction schedule inevitably changes, specific times should be included in the schedule for IAQ testing. These should be selected in consultation with those doing the IAQ testing to avoid times at which other activities in the building might interfere with the testing. The IAQ testing schedule also needs to be sufficiently flexible to deal with situations in which such confounding activities do occur or in which the ventilation system is not operating as desired.

Flexibility of the commissioning program is also important in order to address IAQ concerns that arise during construction or early in building occupancy. 


\section{INTRODUCTION}

Building commissioning generally refers to the process of verifying that building mechanical systems are operating as designed. A commissioning program as described in ASHRAE Guideline 1-1989, includes the testing and balancing of air and water handling systems, verifying operation of heating and air conditioning units, and testing building control systems along with other mechanical systems [1]. Commissioning generally does not include the verification of an "acceptable" indoor environment for the building occupants, including factors related to indoor air quality (IAQ). In light of growing concern about indoor air quality, IAQ commissioning could become an important part of building commissioning programs and could help provide a safe and comfortable working environment for the building occupants as well as reducing other problems related to building operation. There are currently no standard IAQ commissioning protocols. Efforts to date have ranged from limited pre- and post-occupancy surveys to long-term monitoring efforts involving elaborate installations of instrumentation [2 - 4].

In order to identify and understand the issues involved in implementing such a program, a pilot IAQ commissioning program was developed and applied to the new NRC office building in Rockville Maryland. This commissioning program is not presented as a candidate for a standardized protocol for IAQ commissioning. Instead, it is viewed as a pilot program to provide experience and insight that will assist in the development of future IAQ commissioning protocols. The program described in this paper consists of three tasks: (1) evaluate the mechanical ventilation system design from an indoor air quality perspective; (2) develop a set of environmental performance parameters and associated reference values that will be used to evaluate IAQ in the building; and, (3) measure these environmental parameters in the building and compare them with the reference values developed in Task 2.

In Task 1, the ventilation system design was compared to the 1987 BOCA National Mechanical Code [5], to which the building mechanical systems were designed. In addition, the design was compared to ASHRAE (American Society of Heating, Refrigerating and Air-conditioning Engineers, Inc.) Standard 62-1989 [6]. In Task 2, a set of environmental parameters and reference values for these parameters were developed based on a review of standards, guidelines and research literature. In Task 3, these environmental parameters were measured in three phases of building construction: (1) Interior build-out complete, (2) System furniture installed, and (3) Approximately one month after occupancy. The interior build-out consisted of interior framing and sheetrock, painting the sheetrock, and installation of ductwork, dropped ceilings, lighting and carpet. The wall systems installed prior to the Phase 2 testing are modular floor-to-ceiling partitions used to form individual offices and conference rooms. The systems furniture consists of office cubicles separated by fabric-covered partitions approximately $2 \mathrm{~m}(6 \mathrm{ft})$ high furnished with modular office equipment. 


\section{BUILDING DESCRIPTION}

\section{Building Layout}

The NRC building consists of ten floors above grade (Levels 1 through 10), five below grade (Levels A through E), and a penthouse level which houses mechanical equipment. Floors 2 through 10 are similar to each other and consist primarily of open office space which is divided into workstations by office systems furniture. Some of the floors also contain meeting rooms. The main entrance to the building is on Level 1, which also contains common facilities such as the cafeteria, exercise facility, and employee credit union. Level $\mathrm{A}$ is below grade in the front of the building and above grade in the rear, and consists mainly of a daycare center and part of the parking garage. A two-story auditorium is located on Level B and extends up to Level A. The parking garage extends from Level A down to Level E. The parking levels are referred to as P1 through P5, with P5 being the lowest level. There are three core areas in the building. These are the elevators, located at the center of the building, and two stairwells located at the north and south ends of the building.

\section{Mechanical Ventilation System}

The mechanical ventilation system is a variable air volume (VAV) system with a constant outdoor air intake rate. Two outdoor air intake fans located in the penthouse provide outdoor air to all of the air handlers in the building. There are two mechanical rooms located on each of Levels 2 through 10, and each mechanical room contains a supply air handler which provides supply air to one side of the floor. Other air handlers provide supply air to the first floor lobby, daycare center, auditorium, and other areas of the building. Exhaust fans are provided to exhaust the restrooms, garage, and other areas such as janitorial closets, as well as for smoke control.

Figure 1 is a schematic of an air handling system for a typical floor. The major components shown in Figure 1 are the outdoor air intake fan, the mechanical room, the supply air handler, the terminal units or VAV boxes, the supply air diffusers, and the thermostats associated with the terminal units. Under the occupied mode of operation, the two outdoor air intake fans in the penthouse were designed to provide a constant volume of outdoor airflow to each mechanical room, regardless of the supply airflow rate being delivered by the supply air handlers. Outdoor air and return air mix inside the mechanical room to make up the supply air delivered to the occupied space of the building. The supply air is conditioned at the air handler to a temperature of approximately $7.8^{\circ} \mathrm{C}\left(46^{\circ} \mathrm{F}\right)$. The ventilation system is referred to as a cold-air distribution system, compared to most commercial building ventilation systems with a supply air temperatures of about $13^{\circ} \mathrm{C}\left(55^{\circ} \mathrm{F}\right)$. With the exception of the fourth floor, there is no provision for humidification by the building air handlers.

The entire system is controlled by an Environmental Management and Control System (EMCS). The EMCS is a computer-controlled system which automatically monitors and adjusts the environmental conditions throughout the building. The EMCS can also be used to change the mechanical system set-points such as space temperatures. In the case of the supply air handlers and terminal units, the set-point static pressures and temperatures can be adjusted by a building engineer through the EMCS. The EMCS also monitors the actual pressure and temperature and provides the logic which controls the adjustment of the supply fan inlet and terminal unit dampers. Some of the control signals associated with the EMCS system are represented by thin dashed lines in Figure 1. 
Cold-air distribution systems require special supply air diffusers in order to provide thermally acceptable conditions within the occupied zone. The supply air diffusers in this building are designed specifically for use in a cold-air distribution system. These diffusers discharge supply air horizontally at much higher velocities and lower temperatures than would be acceptable in the occupied space. These diffusers are designed to entrain room air into the airstream discharging from the diffuser, such that the air velocity is reduced and the air temperature is increased before it enters the occupied portion of the space.

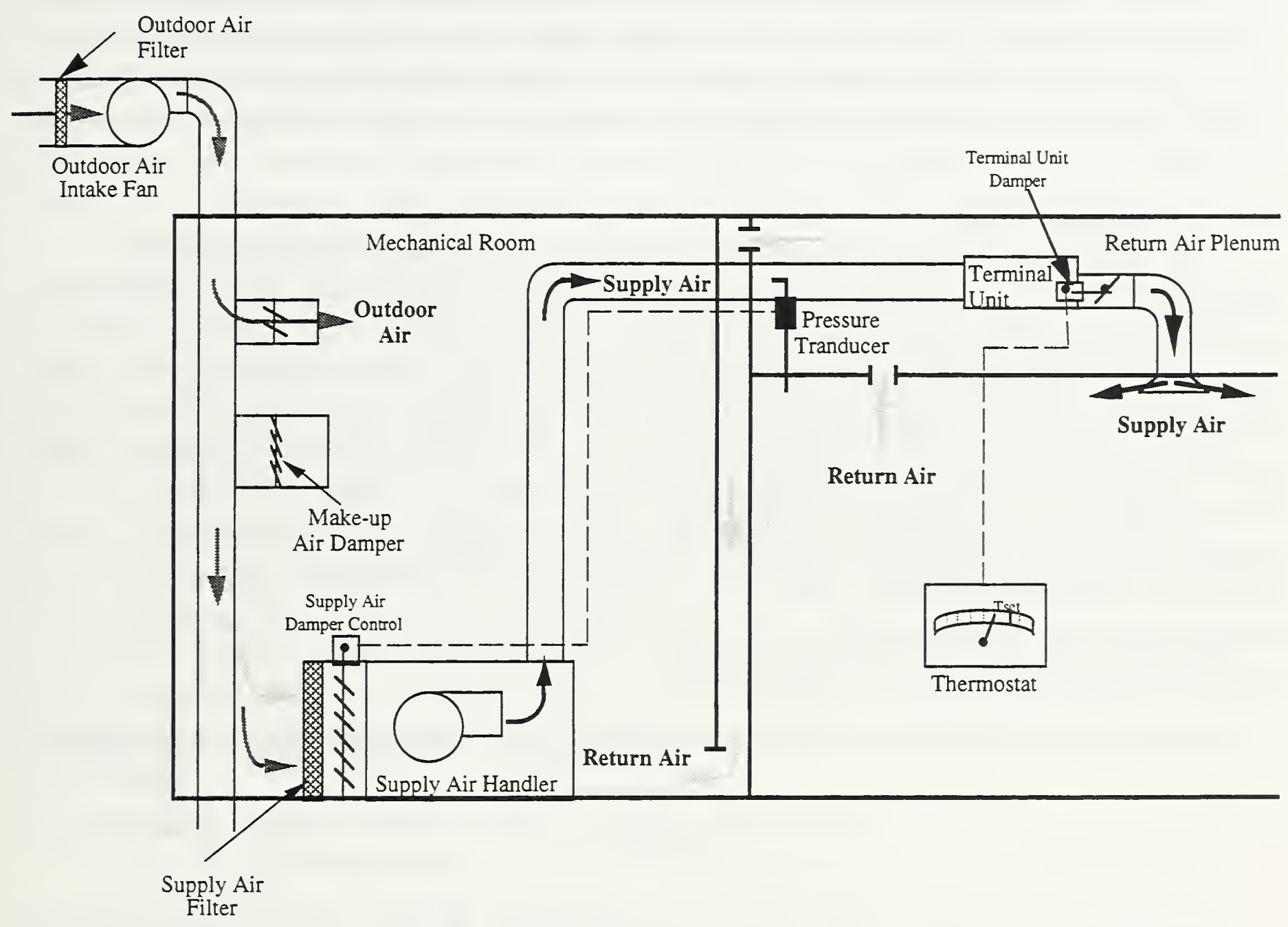

Figure 1 - Schematic of Ventilation System 


\section{TASK 1: DESIGN EVALUATION}

The purpose of Task 1 was to evaluate the mechanical ventilation system design and compare it to relevant codes and standards. Both the 1987 BOCA National Mechanical Code and ASHRAE Standard 62-1989 were used as a basis of comparison with the mechanical ventilation system design. This evaluation was performed in terms of indoor air quality related issues such as minimum outdoor air intake rates and local exhaust strategies. The evaluation of the ventilation system design was based on mechanical drawings and specifications for the base building and mechanical, architectural, and space-use drawings for the interior build-out [7 - 11]. Some significant changes have been made in the building design since this evaluation took place. The most notable change is that the fitness area is not located on the second floor, instead this area will be used as office space and the fitness center will be located on the first floor. Also, a no-smoking policy has been adopted for the entire building.

\section{BOCA Mechanical Code}

The design ventilation rates were based on the 1987 BOCA National Mechanical Code. Therefore, the design was evaluated in comparison to the BOCA Mechanical Code. The BOCA code sets forth minimum ventilation requirements based on the occupancy of a room. Ventilation rates are given in terms of minimum amounts of supply air per person or per floor area depending on the type of space use. The code also specifies maximum allowable recirculation rates. Up to two-thirds of the required ventilation air may be recirculated (minimum of one-third outdoor air), if particulate levels in the ventilation air are less than those specified in Table 1 (Table M-1603.2.1 of the BOCA Mechanical Code). Up to eighty-five percent of the required ventilation air may be recirculated, if filtering or absorption equipment is used which maintains the ventilation air within all of the contaminant limits set forth in Table 1 . However, even with recirculation the outdoor air quantity shall not be less than $2.4 \mathrm{~L} / \mathrm{s}(5 \mathrm{cfm})$ per person.

\begin{tabular}{|c|c|c|c|}
\hline Contaminant & $\begin{array}{l}\text { Annual average } \\
\text { (arithmetic mean) } \\
{\left[\mu \mathrm{g} / \mathrm{m}^{3}\right]}\end{array}$ & $\begin{array}{l}\text { Short-term level } \\
\text { (not to be } \\
\text { exceeded more } \\
\text { than once a year) } \\
{\left[\mu \mathrm{g} / \mathrm{m}^{3}\right]}\end{array}$ & $\begin{array}{l}\text { Averaging } \\
\text { period } \\
\text { [hours] }\end{array}$ \\
\hline Particulates & 60 & 150 & 24 \\
\hline Sulfur oxides & 80 & 400 & 24 \\
\hline Carbon monoxide & 20,000 & 30,000 & 8 \\
\hline Photochemical oxidant & 100 & 500 & 1 \\
\hline Hydrocarbons (not including methane) & 1,800 & 4,000 & 3 \\
\hline Nitrogen oxides & 200 & 5,000 & 24 \\
\hline Odor & \multicolumn{3}{|c|}{ Essentially unobjectionable ${ }^{a}$} \\
\hline
\end{tabular}

Note a. Judged unobjectionable by 60 percent of a panel of 10 untrained subjects.

Table 1 - Maximum Allowable Contaminant Concentrations for Ventilation Air [5] 
The BOCA code also has requirements that all toilet and bath rooms be ventilated by one of several methods along with providing $12 \mathrm{~L} / \mathrm{s}(25 \mathrm{cfm})$ of supply air per water closet or urinal. Assuming one-third outdoor air in the supply air, this requirement corresponds to $4 \mathrm{~L} / \mathrm{s}(8.3 \mathrm{cfm})$ of outdoor air per water closet or urinal. The BOCA code also requires that the exhaust rate be greater than or equal to the design supply airflow capacity for the room.

\section{ASHRAE Standard 62-1989}

The ventilation system design was also compared to ASHRAE Standard 62-1989. While the building was not specifically designed to conform with Standard 62-1989, this standard is gaining wide acceptance as a basis for designing buildings to achieve acceptable IAQ. The standard contains two design procedures, the Ventilation Rate Procedure and the Indoor Air Quality Procedure. The design was evaluated with respect to the Ventilation Rate Procedure which is more commonly used by designers. As noted below, the minimum outdoor air intake rates recommended in ASHRAE Standard 62-1989 are significantly greater than those given in the BOCA Mechanical Code.

The first step in utilizing the Ventilation Rate Procedure is to provide outdoor air which is considered acceptable. Specific procedures for determining acceptability of outdoor air are given in the standard. If the outdoor air does not meet criteria for acceptability, the air should be treated to control offending contaminants. Upon establishing acceptable outdoor air for ventilation, the standard sets forth recommended minimum outdoor airflow rates. The standard provides outdoor airflow rates for various space types on either a per person or floor area basis. The recommended minimum ventilation rates given in Standard 62 "were selected to reflect the consensus that the provision of acceptable outdoor air at these rates would achieve an acceptable level of indoor air quality by reasonably controlling $\mathrm{CO}_{2}$, particulates, odors, and other contaminants common to those spaces." [6]

ASHRAE requires a minimum outdoor airflow rate of $25 \mathrm{~L} / \mathrm{s}(50 \mathrm{cfm})$ per water closet for all public restrooms. Standard 62-1989 also recommends the provision of mechanical exhaust with no recirculation of the exhausted air back into the building, although it does not provide recommended exhaust rates.

\section{Comparison of Ventilation System Design to BOCA and ASHRAE}

The BOCA code allows for air recirculation if the particulate levels in the ventilation air are kept below a specific limit. Increased recirculation is allowed if additional levels of other pollutants are kept below their specified limits. The ASHRAE Standard requires an analysis of outdoor pollutant levels and also requires the use of air cleaning if the outdoor levels exceed certain limits specified in the standard. The design documentation reviewed by NIST does not address assumed pollutant levels in the ventilation or outdoor air, nor does it address air cleaning to justify air recirculation.

Tables 2 and 3 list the main air handler numbers, the design supply airflow capacity of these air handlers, the design outdoor airflow rates, the zone served by the air handler, the floor area of the zone, the design or estimated occupancy of the zone, the design outdoor airflow rate, and the minimum outdoor airflow rates based on the 1987 BOCA National Mechanical Code and ASHRAE Standard 62-1989. Design occupancies for all zones shown in Tables 2 and 3 are based on the space 
plan drawings. Recommended outdoor airflow rates are given in units of flow rate per person or unit floor area depending on the type of space. Tables 2 and 3 provide the same information, with Table 2 in SI units and Table 3 in inch-pound units.

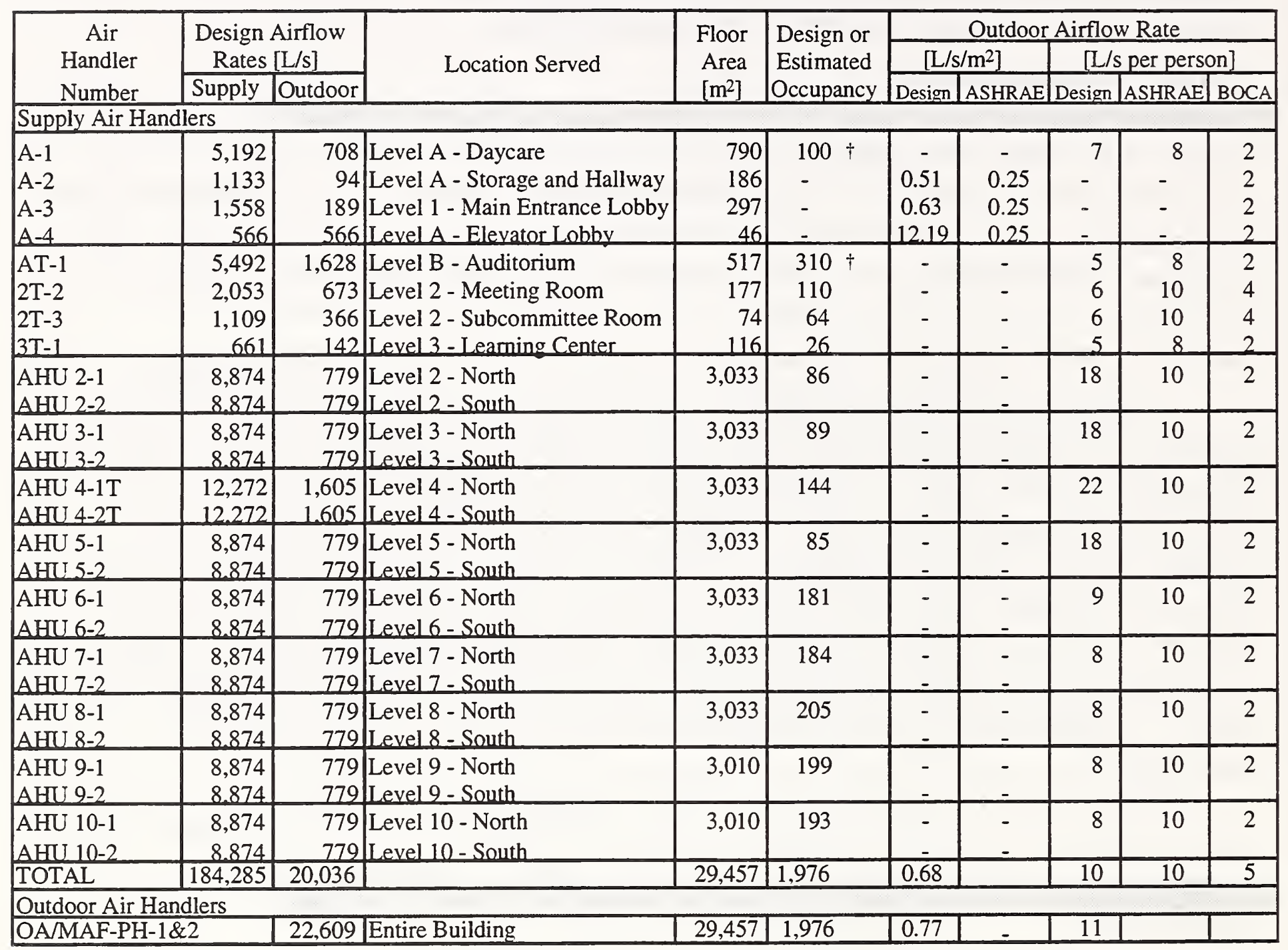

$\dagger$ Maximum occupancy

Table 2 - Design Outdoor Air Intake Rates (SI units) 


\begin{tabular}{|c|c|c|c|c|c|c|c|c|c|c|}
\hline \multirow{3}{*}{$\begin{array}{c}\text { Air } \\
\text { Handler } \\
\text { Number } \\
\end{array}$} & \multirow{2}{*}{\multicolumn{2}{|c|}{$\begin{array}{c}\text { Design Airflow } \\
\text { Rates [cfm] }\end{array}$}} & \multirow{3}{*}{ Location Served } & \multirow{3}{*}{$\begin{array}{l}\text { Floor } \\
\text { Area } \\
{\left[\mathrm{ft}^{2}\right]}\end{array}$} & \multirow{3}{*}{$\begin{array}{l}\text { Design or } \\
\text { Estimated } \\
\text { Occupancy }\end{array}$} & \multicolumn{5}{|c|}{ Outdoor Airflow Rate } \\
\hline & & & & & & \multicolumn{2}{|c|}{$\left[\mathrm{cfm} / \mathrm{ft}^{2}\right]$} & \multicolumn{3}{|c|}{ [cfm per person] } \\
\hline & Supply & Outdoor & & & & Design & ASHRAE & Design & ASHRAE & $\mathrm{BOCA}$ \\
\hline \multicolumn{11}{|c|}{ Supply Air Handlers } \\
\hline A-1 & 11,000 & 1,500 & Level A - Daycare & 8,500 & $100 \div$ & - & - & 15 & 15 & 5 \\
\hline$A-2$ & 2,400 & 200 & Level A - Storage and Hallway & 2,000 & - & 0.10 & 0.05 & - & - & 5 \\
\hline A-3 & 3,300 & 400 & Level 1 - Main Entrance Lobby & 3,200 & - & 0.13 & 0.05 & - & - & 5 \\
\hline$A-4$ & 1.200 & 1200 & Level A - Elevator Lobby & 500 & - & 2.40 & 0.05 & & & 5 \\
\hline AT-1 & 11,635 & 3,450 & Level B - Auditorium & 5,570 & $310 \div$ & - & - & 11 & 15 & 5 \\
\hline $2 \mathrm{~T}-2$ & 4,350 & 1,425 & Level 2 - Meeting Room & 1,900 & 110 & - & - & 13 & 20 & 8 \\
\hline $2 \mathrm{~T}-3$ & 2,350 & 775 & Level 2 - Subcommittee Room & 800 & 64 & - & - & 12 & 20 & 8 \\
\hline $3 \mathrm{~T}-1$ & 1.400 & 300 & Level 3 - Learning Center & 1.250 & 26 & - & - & 12 & 15 & 5 \\
\hline AHU 2-1 & $\begin{array}{l}18,800 \\
18,800\end{array}$ & 1,650 & Level 2 - North & 32,650 & 86 & - & - & 38 & 20 & 5 \\
\hline $\begin{array}{l}\text { AHU 3-1 } \\
\text { AHU 3-2 }\end{array}$ & $\begin{array}{l}18,800 \\
18,800\end{array}$ & $\begin{array}{l}1,650 \\
1,650\end{array}$ & $\begin{array}{l}\text { Level } 3 \text { - North } \\
\text { Level 3 - South }\end{array}$ & 32,650 & 89 & - & - & 37 & 20 & 5 \\
\hline $\begin{array}{l}\text { AHU 4-1T } \\
\text { AHU 4-2T }\end{array}$ & $\begin{array}{l}26,000 \\
26.000\end{array}$ & $\begin{array}{l}3,400 \\
3.400\end{array}$ & $\begin{array}{l}\text { Level } 4 \text { - North } \\
\text { Level } 4 \text { - South }\end{array}$ & 32,650 & 144 & - & - & 47 & 20 & 5 \\
\hline $\begin{array}{l}\text { AHU 5-1 } \\
\text { AHU 5-2 }\end{array}$ & $\begin{array}{l}18,800 \\
18,800\end{array}$ & $\begin{array}{l}1,650 \\
1650 \\
\end{array}$ & $\begin{array}{l}\text { Level } 5 \text { - North } \\
\text { Level } 5 \text { - South }\end{array}$ & 32,650 & 85 & - & - & 39 & 20 & 5 \\
\hline $\begin{array}{l}\text { AHU 6-1 } \\
\text { AHU 6-2 }\end{array}$ & $\begin{array}{l}18,800 \\
18,800\end{array}$ & $\begin{array}{l}1,650 \\
1,650 \\
\end{array}$ & $\begin{array}{l}\text { Level } 6 \text { - North } \\
\text { Level } 6 \text { - South }\end{array}$ & 32,650 & 181 & - & - & 18 & 20 & 5 \\
\hline $\begin{array}{l}\text { AHU 7-1 } \\
\text { AHU 7-2 }\end{array}$ & $\begin{array}{l}18,800 \\
18,800 \\
\end{array}$ & $\begin{array}{l}1,650 \\
1,650 \\
\end{array}$ & $\begin{array}{l}\text { Level } 7 \text { - North } \\
\text { Level } 7 \text { - South }\end{array}$ & 32,650 & 184 & - & - & 18 & 20 & 5 \\
\hline $\begin{array}{l}\text { AHU 8-1 } \\
\text { AHU 8-2 }\end{array}$ & $\begin{array}{l}18,800 \\
18,800 \\
\end{array}$ & $\begin{array}{r}1,650 \\
1,650 \\
\end{array}$ & $\begin{array}{l}\text { Level } 8 \text { - North } \\
\text { Level } 8 \text { - South }\end{array}$ & 32,650 & 205 & - & - & 16 & 20 & 5 \\
\hline $\begin{array}{l}\text { AHU 9-1 } \\
\text { AHU 9-2 }\end{array}$ & $\begin{array}{l}18,800 \\
18.800 \\
\end{array}$ & $\begin{array}{l}1,650 \\
1.650 \\
\end{array}$ & $\begin{array}{l}\text { Level } 9 \text { - North } \\
\text { Level } 9 \text { - South }\end{array}$ & 32,400 & 199 & - & - & 17 & 20 & 5 \\
\hline $\begin{array}{l}\text { AHU 10-1 } \\
\text { AHU 10-2 }\end{array}$ & $\begin{array}{l}18,800 \\
18.800\end{array}$ & $\begin{array}{l}1,650 \\
1.650\end{array}$ & $\begin{array}{l}\text { Level } 10 \text { - North } \\
\text { Level } 10 \text { - South }\end{array}$ & 32,400 & 193 & - & - & 17 & 20 & 5 \\
\hline TOTAL & 390.435 & 42.450 & & 317.070 & 1.976 & 0.13 & & 21 & 20 & 5 \\
\hline \multicolumn{11}{|c|}{ Outdoor Air Handlers } \\
\hline OAMAF-PH & & 47.900 & Entire Building & 317.070 & 1.976 & 0.15 & & 24 & & \\
\hline
\end{tabular}

$\div$ Maximum occupancy

Table 3 - Design Outdoor Air Intake Rates (inch-pound units)

The design outdoor air intake rates of all zones listed in Tables 2 and 3 exceed the rates required by the BOCA Mechanical Code. Level 4 has a higher design outdoor airflow rate, even though the design occupancy is less than on Levels 6 through 10. The design outdoor air intake rate is higher for the fourth floor because it contains the special operations center, which has a high peak occupancy that was not available in the design documentation. This higher occupancy level was apparently used to determine the design outdoor air intake rate for the fourth floor. The design outdoor airflow rates for Levels 2 through 10, with the exception of Level 4, are all the same independent of the number of occupants designated for the zones. There are no estimated occupant densities found for hallways, entrances, or lobbies in either the BOCA Code or ASHRAE Standard 62-1989. Therefore, design outdoor airflow rates per person could not be calculated for air handlers A-2, A-3, and A-4 for comparison with the BOCA requirement. However, the design outdoor air intake rate for the spaces 
served by these air handlers (Level A Storage and Hallway, Main Entrance Lobby on Level 1, and Elevator Lobby on Level A) can be compared with ASHRAE on a L/s $\bullet \mathrm{m}^{2}\left(\mathrm{cfm} / \mathrm{ft}^{2}\right)$ basis. For the first two spaces, the design value is roughly two times the ASHRAE minimum outdoor air requirement. In the case of the Elevator Lobby on Level A, the design value is almost fifty times the ASHRAE minimum.

Although the building was not designed to ASHRAE Standard 62-1989, comparisons of design outdoor airflow rates to the ASHRAE recommendations reveal that most of the design values are above or just below the minimum outdoor airflow rates recommended in ASHRAE Standard 62-1989. Levels 6 through 10 have design values that are between 5\% and 20\% less than ASHRAE recommended levels of outdoor airflow rate. These levels are made up of mostly open office space and have some of the highest occupant levels in the building. Outdoor airflow rates to Levels 2 through 5 are much higher than the ASHRAE recommended levels. The daycare center, auditorium, fitness center, Level 2 meeting room, and learning center have design outdoor airflow rates which are between 25\% and 50\% below levels recommended in ASHRAE Standard 62-1989. Based on the total design occupancy and the capacity of the outdoor air intake fans (the last entry in Tables 2 and 3 ), the design outdoor airflow rate for the entire building is approximately $11 \mathrm{~L} / \mathrm{s}$ per person $(23 \mathrm{cfm}$ per person) which is greater than the ASHRAE Standard 62-1989 recommendation.

Exhaust and ventilation air requirements for the main restrooms on Levels 2 through 10 were compared to both BOCA and ASHRAE Standard 62-1989. The men's rooms each have five water closets and the ladies' rooms each have four water closets. The design exhaust flow rates are $283 \mathrm{~L} / \mathrm{s}$ $(600 \mathrm{cfm})$ for each restroom. Therefore, the design exhaust rates are $57 \mathrm{~L} / \mathrm{s}(120 \mathrm{cfm})$ and $71 \mathrm{~L} / \mathrm{s}$ $(150 \mathrm{cfm})$ per water closet for the men's and ladies' rooms respectively. Each restroom has a design supply airflow rate of $47 \mathrm{~L} / \mathrm{s}(100 \mathrm{cfm})$ which translates to an outdoor airflow rate of $0.9 \mathrm{~L} / \mathrm{s}(2.0 \mathrm{cfm})$ and $1.2 \mathrm{~L} / \mathrm{s}(2.5 \mathrm{cfm})$ per water closet for the men's and ladies' rooms respectively, based on the ratio of design outdoor air to supply air (approximately ten percent based on the supply fan capacities). As required by BOCA, the design exhaust rates are greater than the design supply airflow rate. Based on these values, design outdoor airflow rates for the restrooms are below both the BOCA and ASHRAE requirements. However, transfer ducts are located between the return air plenum above the ceiling in the main office area and each restroom to allow for the provision of "make-up" air to the restrooms. Assuming that the total airflow rate to the restrooms consists of supply air and transfer air, is equal to the exhaust airflow rate of $283 \mathrm{~L} / \mathrm{s}(600 \mathrm{cfm})$, and contains ten percent outdoor air, the outdoor airflow rate would be approximately $5.7 \mathrm{~L} / \mathrm{s}(12 \mathrm{cfm})$ and $7 \mathrm{~L} / \mathrm{s}(15 \mathrm{cfm})$ per water closet for the men's and ladies' rooms respectively. These values are above the $4 \mathrm{~L} / \mathrm{s}(8.3 \mathrm{cfm})$ per water closet required by BOCA, but still below the outdoor airflow rate of $25 \mathrm{~L} / \mathrm{s}(50 \mathrm{cfm})$ per water closet in ASHRAE Standard 62-1989. 


\section{TASK 2: INDOOR ENVIRONMENTAL PARAMETERS}

Task 2 consisted of the development of a set of parameters to characterize the indoor environment in the building and the selection of reference values for these parameters to be compared to their measured values. Ideally, these parameters and the associated reference values would be based on existing standards. However, in most cases there are no indoor air quality standards for office buildings; therefore, the reference values were based on other guidelines and the results of previous IAQ research efforts. There are three categories of indoor environmental parameters that were measured in the building: ventilation performance, pollutants, and thermal comfort. The following is a list of the parameters that were measured as part of the commissioning program.

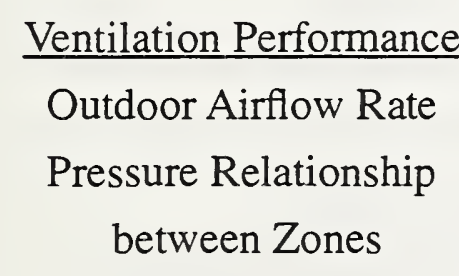

\author{
Pollutants \\ Carbon Dioxide \\ Carbon Monoxide \\ Formaldehyde \\ Particulates \\ Radon

\section{Volatile Organic Compounds}

\author{
Thermal Comfort \\ Temperature \\ Relative Humidity \\ Operative Temperature
}

The existing criteria for these parameters and the reference values that were selected for this project are presented in the following sections. The reference values are not intended to strictly define an acceptable indoor environment, but are meant to provide an indication of the acceptability of the environment based on the limited information that is currently available and to identify the potential for situations of concern in the building.

\section{Existing Criteria}

Table 4 contains criteria that exist for each of the project parameters and the sources of these criteria. Some of the criteria are based on current standards which are applicable to office and other indoor environments; other criteria are based on guidelines and information from the scientific community involved with indoor air quality. Explanations of each criteria listed in Table 4 are given following the table. 


\begin{tabular}{|c|c|c|}
\hline Parameter & Criteria & Reference \\
\hline \multirow[t]{2}{*}{ Outdoor Airflow Rate } & $10 \mathrm{~L} / \mathrm{s}(20 \mathrm{cfm})$ per person & ASHRAE $62-1989$, Table 2 \\
\hline & $2.5 \mathrm{~L} / \mathrm{s}(5 \mathrm{cfm})$ per person & $\begin{array}{l}\text { BOCA National Mechanical Code 1990, } \\
\text { Table M-1603.2.1 }\end{array}$ \\
\hline \multirow[t]{2}{*}{$\begin{array}{l}\text { Pressure } \\
\text { Relationships } \\
\text { between Zones }\end{array}$} & $\begin{array}{l}\text { Restrooms mechanically exhausted with no } \\
\text { recirculation. }\end{array}$ & $\begin{array}{l}\text { ASHRAE } 62-1989, \text { Table } 2 \\
\text { BOCA National Mechanical Code } 1990 \text {, } \\
\text { Section M-1603.4 }\end{array}$ \\
\hline & $\begin{array}{l}\text { Restroom design exhaust capacity shall be } \\
\text { greater than or equal to the design supply } \\
\text { capacity }\end{array}$ & $\begin{array}{l}\text { BOCA National Mechanical Code } 1990 \text {, } \\
\text { Section M-1602.9.3 }\end{array}$ \\
\hline Carbon Dioxide & $1000 \mathrm{ppm}$ & ASHRAE 62-1989 [6], Table 3 \\
\hline \multirow[t]{3}{*}{ Carbon Monoxide } & $\begin{array}{l}9 \mathrm{ppm}, 8 \text {-hour average } \\
35 \mathrm{ppm}, 1 \text {-hour average }\end{array}$ & $\begin{array}{l}\text { EPA - National Ambient Air Quality Standards [12] } \\
\text { (ASHRAE 62-1989, Table C-1) }\end{array}$ \\
\hline & $\begin{array}{l}\text { Less than } 9.6 \mathrm{ppm} \text {, limited or no concern } \\
\text { Greater than } 26 \mathrm{ppm} \text {, concentration of concern }\end{array}$ & $\begin{array}{r}\text { WHO [13] - Continuous exposure } \\
\text { (ASHRAE 62-1989, Table C-4) }\end{array}$ \\
\hline & $\begin{array}{l}17 \mathrm{ppm} \text {, annual average } \\
26 \mathrm{ppm}, 24 \text {-hour average }\end{array}$ & $\begin{array}{l}\text { BOCA National Mechanical Code } 1990 \text { [5], } \\
\text { Table M-1603.2.1 }\end{array}$ \\
\hline \multirow[t]{2}{*}{ Formaldehyde } & $0.40 \mathrm{ppm}$, target level for homes & $\begin{array}{l}\text { HUD - standard for manufactured homes [14] } \\
\text { (ASHRAE 62-1989 Table C-1) }\end{array}$ \\
\hline & $\begin{array}{l}0.05 \mathrm{ppm} \text {, limited or no concern } \\
0.10 \mathrm{ppm} \text {, concentration of concern }\end{array}$ & $\begin{array}{l}\text { WHO - Long and short-term exposure } \\
\text { (ASHRAE 62-1989 Table C-4) }\end{array}$ \\
\hline \multirow[t]{2}{*}{ Particulates } & $\begin{array}{c}50 \mu \mathrm{g} / \mathrm{m}^{3} \text {, annual average (PM 10) } \\
150 \mu \mathrm{g} / \mathrm{m}^{3}, 24 \text {-hour average (PM 10) }\end{array}$ & $\begin{array}{l}\text { EPA - National Ambient Air Quality Standards } \\
\text { (ASHRAE 62-1989 Table 1) }\end{array}$ \\
\hline & $\begin{array}{c}60 \mu \mathrm{g} / \mathrm{m}^{3}, \text { annual average } \\
150 \mu \mathrm{g} / \mathrm{m}^{3}, 24 \text {-hour average }\end{array}$ & $\begin{array}{l}\text { BOCA National Mechanical Code } 1990 \text { [5], } \\
\text { Table M-1603.2.1 }\end{array}$ \\
\hline Radon & $\begin{array}{l}\text { Action level for homes: } \\
4 \mathrm{pCi} / \mathrm{L} \text { (picocuries per liter) }\end{array}$ & $\begin{array}{l}\text { EPA } 1988 \text { - Radon Reduction Techniques for Detached } \\
\text { Houses, Technical Guidance. } \\
\text { (ASHRAE 62-1989 Table 3) }\end{array}$ \\
\hline $\begin{array}{l}\text { Total Volatile Organic } \\
\text { Compounds (TVOC) }\end{array}$ & $\begin{array}{l}\text { Comfort range: } \\
\text { less than } 200 \mu \mathrm{g} / \mathrm{m}^{3} \\
\text { Multifactorial exposure range: } \\
200-3000 \mu \mathrm{g} / \mathrm{m}^{3} \\
\text { Discomfort range: } \\
3000-25000 \mu \mathrm{g} / \mathrm{m}^{3} \\
\text { Toxic exposure range: } \\
\text { greater than or equal to } 25000 \mu \mathrm{g} / \mathrm{m}^{3}\end{array}$ & $\begin{array}{l}\text { Mølhave, Indoor Air ' } 91 \text { [15] } \\
\text { This is not a standard, but is based on a combination } \\
\text { of field and controlled climate chamber tests. }\end{array}$ \\
\hline \multirow[t]{2}{*}{ Thermal Comfort } & \multirow{2}{*}{$\begin{array}{l}\text { Predicted Percent Dissatisfied (PPD) } \\
\text { less than or equal to } 10 \%\end{array}$} & ASHRAE Standard 55-1992 [16] \\
\hline & & $\begin{array}{l}\text { ISO Standard } 7730 \text { [17] } \\
\text { Recommendation given in Annex A which is not part } \\
\text { of the standard }\end{array}$ \\
\hline
\end{tabular}

Table 4 - Existing IAQ Criteria 


\section{Ventilation Performance}

Outdoor Airflow Rate - Two standards for minimum outdoor airflow rates are presented in Table 4. They are the BOCA National Mechanical Code and ASHRAE Standard 62-1989. The BOCA Code sets forth an absolute minimum outdoor air intake rate of $2.5 \mathrm{~L} / \mathrm{s}(5 \mathrm{cfm})$ per person. ASHRAE Standard 62-1989 provides two procedures which can be used in buildings to provide adequate indoor air quality for human occupancy. These methods are referred to as the Ventilation Rate Procedure and the Indoor Air Quality Procedure. The Ventilation Rate Procedure is the more commonly used procedure in the design of building mechanical ventilation systems and requires minimum levels of outdoor air per person that depends on the type of space. Table 4 of this report indicates the minimum ventilation rate in the ASHRAE Standard for office space of $10 \mathrm{~L} / \mathrm{s}(20 \mathrm{cfm})$ per person.

Pressure Relationships between Zones - The relationship of individual spaces to each other in terms of airflow and the potential for pollutant transport is of concern in the design and operation of a mechanical ventilation system. As indicated in the BOCA Mechanical Code and ASHRAE Standard 62-1989, restrooms should be mechanically exhausted, and the exhaust air from the restrooms should not be recirculated back to the occupied space. The BOCA Code also requires restroom design exhaust flow rates to be greater than the design supply airflow rates in order to negatively pressurize the restrooms relative to adjoining spaces.

Another aspect of pressure relationships between building zones is based on recommended practices during construction to reduce the potential for the transport of construction-related contaminants to other zones [18]. During construction activity, those zones or floors upon which construction is completed should be isolated from those in which construction is still in progress. This could be accomplished by adjusting supply and exhaust airflow rates so that air flows from completed zones into the stairways and elevator shafts and from the stairs and elevator shafts into the construction zones. In this way contaminants from construction zones will be hindered from flowing into completed zones. These adjustments can be made using the building mechanical system and/or by installing temporary exhaust systems to exhaust the construction zones directly to the outdoors.

\section{Pollutants}

Carbon Dioxide - Carbon dioxide is produced by the occupants of a building and can be a useful indicator of the adequacy of outdoor air ventilation rates per person in controlling human body odor. ASHRAE Standard 62-1989 provides a recommended maximum level of $\mathrm{CO}_{2}$ of 1000 ppm (parts per million). According to ASHRAE, this level of $\mathrm{CO}_{2}$ is not a health risk but is a surrogate for odors produced by humans. It is stated in the standard that "comfort (odor) criteria are likely to be satisfied if the ventilation rate is set so that 1000 ppm of $\mathrm{CO}_{2}$ is not exceeded." Even if this criteria is met, it does not mean that other contaminants will not reach levels of concern within the indoor environment.

Carbon Monoxide - Carbon monoxide is a product of combustion associated with cooking, some heating systems, and motor vehicles. This building has an underground garage, which is a potential source of $\mathrm{CO}$ for the interior of the building. Ambient levels of $\mathrm{CO}$ typically do not exceed 2 ppm, except in urban environments. Therefore, if indoor levels of $\mathrm{CO}$ are about $5 \mathrm{ppm}$ or more, it is 
probably an indication that there is some source of $\mathrm{CO}$ impacting the indoor environment. There are no standards for maximum $\mathrm{CO}$ levels for office environments, but other guidelines are available and are listed in Table 4. Guidelines for outdoor air are set forth by the U.S. Environmental Protection Agency (EPA) in the National Ambient Air Quality Standards. ASHRAE Standard 62-1989 uses these values as a criteria for the acceptability of intake air. According to these criteria, average $\mathrm{CO}$ concentrations are not to exceed $9 \mathrm{ppm}$ over an 8 -hour period and $35 \mathrm{ppm}$ over a 1-hour period. The World Health Organization (WHO) guidance, presented in Appendix C of ASHRAE Standard 62-1989, is based on continuous exposure and is given in terms of concentrations of limited or no concern and concentrations of concern. The BOCA National Mechanical Code contains a guideline for establishing maximum recirculation rates for mechanical ventilation systems. The BOCA code does not indicate that these guidelines should not be exceeded indoors, only that they must be met in order to recirculate return air back to the ventilated space.

Formaldehyde - Indoor sources of formaldehyde include urea-formaldehyde foam insulation, pressed-wood products (particle board, medium density fiberboard, and interior grade hardwood plywood), and some fabrics, especially those treated to be permanent press, soil and wrinkle resistant, and water repellent [19]. There are no formaldehyde standards available for office space in the U.S., but there is a U.S. Housing and Urban Development (HUD) standard for manufactured homes and levels of concern from WHO.

Particulates - Of the various size particles suspended in the air, some are large enough that they settle out onto surfaces while others are small enough to remain suspended in the air by typical air currents in the indoor environment. Particulates which are less than $10 \mu \mathrm{m}$ in diameter (referred to as PM 10) are of concern in terms of human health, as these are respirable by humans. Guidelines for outdoor air particulate levels are given by EPA in the National Ambient Air Quality Standards and are used in ASHRAE Standard 62-1989 as a criteria for the acceptability of intake air. The BOCA National Mechanical Code also presents guideline levels for particulates in the ventilation air of a building; however, these guidelines are provided as a means for determining maximum recirculation rates. The BOCA code does not indicate that these guidelines should not be exceeded indoors, only that they must be met in order to recirculate return air back to the ventilated space.

Radon - Radon is a colorless and odorless radioactive gas which is found in soil at various concentrations. Radon gas can enter a structure through airflow paths in the foundation of a building. Radon then decays radioactively into other ions (progeny) which can attach themselves to particulates in the air and be inhaled by occupants. ASHRAE Standard 62-1989 contains a guideline for radon developed by EPA of $4 \mathrm{pCi} / \mathrm{L}$ for homes. ASHRAE also recommends this as a guideline to be used for other buildings until the development of specific guidelines for other occupancies are published by appropriate authorities.

Volatile Organic Compounds - Volatile organic compounds (VOC) are compounds that evaporate from products made with organic chemicals. Among many other sources, VOCs are emitted by solvents and adhesives used in construction and by many building materials. Some VOCs can be irritating to humans, and some are known to cause adverse health effects at certain concentrations. There are no standards for indoor levels of VOCs. However, a tentative set of 
guidelines for total VOC (TVOC) concentrations in non-industrial indoor environments has been developed based on field investigations and laboratory experiments [15]. TVOC is a simplified approach to characterizing the concentration of volatile organic compounds and is equal to the total mass of all volatile organic compounds in an air sample. There is no standard definition of TVOC, and the value is dependant on the sampling and analytical methods used. The TVOC guidelines in Table 4 are preliminary and based on a limited amount of research. More research and data are needed to develop a more sound set of guidelines. These suggested guidelines break down TVOC levels into four categories of effects on humans: the comfort range in which no irritation is expected; the multifactorial exposure range in which irritation and discomfort is possible if other exposures interact; the discomfort range in which occupant complaints, probable headache, and other exposure effects occur if VOC exposure interacts with exposures other than VOCs; and the toxic exposure range in which headaches and additional neurotoxic effects may occur.

\section{Thermal Comfort}

Predicted Percent Dissatisfied - The control of temperature and relative humidity are important to maintaining occupant comfort in a building. Thermal comfort is a function of air temperature, relative humidity, radiant temperature, air speed, and other occupant-related factors. ASHRAE Standard 55-1992 is dedicated to the provision of thermal comfort of building occupants. This standard provides a comfort zone based on several environmental and occupant-related parameters such as dew-point temperature, relative humidity, operative temperature of the air, occupant activity level (metabolic rate), and insulating value of the clothing worn by the occupants. Operative temperature takes into account the effects of dry-bulb temperature, radiant temperature, and air speed.

The comfort zone in the ASHRAE standard is based on a criterion that a maximum of $10 \%$ of the occupants will be dissatisfied with the thermal environment. International Standard ISO 7730-1984 [17] presents a method for determining thermal comfort indices upon which the ASHRAE Standard 55-1992 comfort zones are based. These indices are referred to as the Predicted Mean Vote (PMV) and the Predicted Percent Dissatisfied (PPD). As stated in ISO 7730, the PMV is an index for predicting the mean value of votes of a large group of persons on a 7-point thermal comfort scale. This scale ranges from -3 (cold) to 0 (neutral) to +3 (hot). The PPD predicts the percentage of occupants likely to feel either too hot or too cold in a given environment and is calculated from the PMV. The ISO standard presents methods for determining these values based on measurements and assumptions of the previously-mentioned environmental and occupant-related parameters. In order to meet the criterion of ASHRAE Standard 55-1992, the PPD should be less than or equal to $10 \%$.

For the purposes of this project, the PPD will be calculated based on ISO 7730-1984 using the thermal comfort measurements performed during Phase 3 of this study along with the following assumptions: a relative air velocity of $0.1 \mathrm{~m} / \mathrm{s}$, convective and radiant heat transfer coefficients that are equal to each other, light summer clothing (insulation value of $0.08 \mathrm{~m}^{2} \cdot{ }^{\circ} \mathrm{C} / \mathrm{W}$ ), and a metabolic rate based on slightly active office work (metabolic rate of $81 \mathrm{~W} / \mathrm{m}^{2}$ or $1.4 \mathrm{met}$ ). 


\section{Project Reference Values}

Table 5 contains the project reference values to which the parameters measured in the NRC building were compared. These values were selected from the available guidelines and criteria presented in Table 4. A brief explanation of each of the project reference values follows the table. As stated earlier, the reference values are not intended to strictly define an acceptable indoor environment, but are meant to provide an indication of the acceptability of the environment based on the limited information that is currently available and to identify the potential for situations of concern in the building.

\begin{tabular}{|l|l|}
\hline \multicolumn{1}{|c|}{ Parameter } & \multicolumn{1}{c|}{ Project Reference Value } \\
\hline Outdoor Airflow Rate & $10 \mathrm{~L} / \mathrm{s}(20 \mathrm{cfm})$ per person \\
\hline $\begin{array}{l}\text { Pressure Relationships } \\
\text { between Zones }\end{array}$ & $\begin{array}{l}\text { Restrooms mechanically exhausted with no } \\
\text { recirculation } \\
\text { Occupied spaces positively pressurized relative } \\
\text { to stairways and elevator shafts during } \\
\text { construction } \\
\text { Construction spaces negatively pressurized } \\
\text { relative to finished spaces }\end{array}$ \\
\hline Carbon Dioxide & $1000 \mathrm{ppm}$ \\
\hline Carbon Monoxide & $10 \mathrm{ppm}$ \\
\hline Formaldehyde & $0.05 \mathrm{ppm}$ \\
\hline Particulates (PM10) & $150 \mu \mathrm{g} / \mathrm{m}^{3}$ \\
\hline Radon & $4 \mathrm{pCi} / \mathrm{L}$ \\
\hline Total Volatile Organic Compounds & $1000 \mu \mathrm{g} / \mathrm{m}^{3}$ \\
\hline PPD & $10 \%$ \\
\hline
\end{tabular}

Table 5 - Project Reference Values

\section{Ventilation Performance}

Outdoor Airflow Rate - The minimum ventilation rate required for office space of $10 \mathrm{~L} / \mathrm{s}$ (20 cfm) per person as given by ASHRAE Standard 62-1989 is the project reference value for outdoor airflow rates. This standard is widely accepted as the basis for ventilation system design for acceptable indoor air quality.

Pressure Relationships between Zones - The relationships presented in Table 5 of this report are based on guidelines for restrooms given in ASHRAE Standard 62-1989, and on suggested practice during construction in order to minimize the effects of construction on indoor air quality [20].

\section{$\underline{\text { Pollutants }}$}

Carbon Dioxide - 1000 ppm is the maximum recommended level of $\mathrm{CO}_{2}$ given in ASHRAE Standard 62-1989. According to ASHRAE, this level of $\mathrm{CO}_{2}$ is not considered a health risk but is a surrogate of human comfort (odor). 
Carbon Monoxide - A maximum concentration of $10 \mathrm{ppm}$ was selected based on the continuous exposure level recommended by the World Health Organization.

Formaldehyde - A maximum value of $0.05 \mathrm{ppm}$ was selected as the project reference value based on the World Health Organization level of limited or no concern.

Particulates - The project reference value of a maximum short term concentration of $150 \mu \mathrm{g} / \mathrm{m}^{3}$ is based on the National Ambient Air Quality Standards set forth by EPA. This value applies to respirable particulates which are less than or equal to $10 \mu \mathrm{m}$ in diameter (PM10).

Radon - The project reference value of $4 \mathrm{pCi} / \mathrm{L}$ is the EPA action level for homes and is recommended in ASHRAE Standard 62-1989.

Volatile Organic Compounds - A guideline maximum TVOC level of $1000 \mu \mathrm{g} / \mathrm{m}^{3}$ is the project reference value for VOC concentrations. This value falls into the multifactorial exposure range of Mølhave's guideline values of TVOC levels.

\section{Thermal Comfort}

Predicted Percent Dissatisfied - The reference value for thermal comfort is that the PPD should be less than or equal to $10 \%$. This is based on recommendations given in ASHRAE and ISO standards. 


\section{TASK 3: INDOOR ENVIRONMENTAL MEASUREMENTS}

This section presents the schedule of construction and environmental monitoring in the building, the measurement techniques used to perform the indoor environmental measurements, and the results of the measurements.

\section{Construction and IAQ Test Schedule}

Indoor environmental measurements were performed in three phases in each of eleven zones of the building. Table 6 indicates the dates of interior work activities and the three phases of measurements performed in each zone. The three phases correspond to different stages in building construction and interior work: (Phase 1) interior build-out complete, (Phase 2) wall and furniture systems installed, and (Phase 3) approximately one month after occupancy. The interior build-out consisted of interior framing and sheetrock, painting the sheetrock, and installation of ductwork, dropped ceilings, lighting and carpet. The wall systems installed prior to the Phase 2 testing are modular floor-to-ceiling partitions used to form individual offices and conference facilities. The systems furniture consists of office cubicles separated by fabric-covered partitions approximately $2 \mathrm{~m}$ $(6 \mathrm{ft})$ high furnished with modular office equipment. No testing was performed in the auditorium during Phase 1. Occupancy occurred in stages beginning with the fourth floor in April 1994; by the end of June 1994 the second through tenth floors were completely occupied. The daycare center began operation at the beginning of the 1994/95 school year in early September. The original plan was to perform one week of environmental measurements in each zone as each stage of construction was completed in that zone. However, in the early phases, some parameters could not be measured due to construction delays and malfunctions of the HVAC system. These delays did not affect the measurements performed in the final phase of measurements. 


\begin{tabular}{|c|c|c|c|c|c|c|}
\hline Zone & $\begin{array}{l}\text { Interior } \\
\text { Build-out } \\
\text { Complete }\end{array}$ & $\begin{array}{c}\text { Phase } 1 \\
\text { Measurements }\end{array}$ & $\begin{array}{l}\text { System Furniture } \\
\text { Installation }\end{array}$ & $\begin{array}{c}\text { Phase } 2 \\
\text { Measurements }\end{array}$ & Occupancy & $\begin{array}{c}\text { Phase } 3 \\
\text { Measurements }\end{array}$ \\
\hline Auditorium & Nov 22, 1993 & $\begin{array}{l}\text { Not monitored } \\
\text { during this phase }\end{array}$ & $\begin{array}{l}\text { No seating } \\
\text { installed until } \\
\text { after Phase } 3\end{array}$ & $\begin{array}{l}\text { Jun 28, } 1994 \text { - } \\
\text { Jul } 05,1994\end{array}$ & N/A & $\begin{array}{l}\text { Sep 13, } 1994 \text { - } \\
\text { Sep 20, } 1994\end{array}$ \\
\hline Daycare Center & Nov 22, 1993 & $\begin{array}{l}\text { Dec 27, } 1993- \\
\text { Jan 03, } 1994\end{array}$ & N/A & $\begin{array}{l}\text { Jun } 15,1994 \text { - } \\
\text { Jun 22, } 1994\end{array}$ & Sep 06, 1994 & $\begin{array}{l}\text { Sep 13, } 1994 \text { - } \\
\text { Sep 20, } 1994\end{array}$ \\
\hline $2^{\text {nd }}$ Floor & Nov 22, 1993 & $\begin{array}{l}\text { Dec 27, } 1993- \\
\text { Jan 03, } 1994\end{array}$ & $\begin{array}{l}\text { Mar 23, } 1994- \\
\text { Apr 26, } 1994\end{array}$ & $\begin{array}{l}\text { Jun 28, } 1994 \text { - } \\
\text { Jul 05, } 1994\end{array}$ & Jun 20, 1994 & $\begin{array}{l}\text { Sep 06, } 1994 \text { - } \\
\text { Sep 13, } 1994\end{array}$ \\
\hline $3^{\text {rd }}$ Floor & Nov 22, 1993 & $\begin{array}{l}\text { Dec 27, } 1993- \\
\text { Jan 03, } 1994\end{array}$ & $\begin{array}{l}\text { Apr 06, } 1994 \text { - } \\
\text { May 10, } 1994\end{array}$ & $\begin{array}{l}\text { Jun 15, } 1994 \text { - } \\
\text { Jun 22, } 1994\end{array}$ & Jul 11, 1994 & $\begin{array}{l}\text { Sep 06, } 1994 \text { - } \\
\text { Sep 13, } 1994\end{array}$ \\
\hline $4^{\text {th }}$ Floor & Nov 22, 1993 & $\begin{array}{l}\text { Nov 22, } 1993- \\
\text { Nov 29, } 1993\end{array}$ & $\begin{array}{l}\text { Dec } 13,1993- \\
\text { Jan } 14,1994\end{array}$ & $\begin{array}{l}\text { Apr 11, } 1994 \text { - } \\
\text { Apr 18, } 1994\end{array}$ & Apr 11, 1994 & $\begin{array}{l}\text { Sep 06, } 1994 \text { - } \\
\text { Sep 13, } 1994\end{array}$ \\
\hline $5^{\text {th }}$ Floor & Nov 22, 1993 & $\begin{array}{l}\text { Nov 22, } 1993- \\
\text { Nov 29, } 1993\end{array}$ & $\begin{array}{l}\text { Dec 30, } 1993- \\
\text { Feb 04, } 1994\end{array}$ & $\begin{array}{l}\text { Apr } 11,1994- \\
\text { Apr } 18,1994\end{array}$ & Apr 18,1994 & $\begin{array}{l}\text { Aug 30, } 1994 \text { - } \\
\text { Sep 06, } 1994\end{array}$ \\
\hline $6^{\text {th }}$ Floor & Nov 22,1993 & $\begin{array}{l}\text { Nov 29, } 1993 \text { - } \\
\text { Dec 06, } 1993\end{array}$ & $\begin{array}{l}\text { Jan } 10,1994- \\
\text { Feb 14, } 1994\end{array}$ & $\begin{array}{l}\text { Apr 18, } 1994 \text { - } \\
\text { Apr 25, } 1994\end{array}$ & Apr 25, 1994 & $\begin{array}{l}\text { Aug 30, } 1994 \text { - } \\
\text { Sep 06, } 1994\end{array}$ \\
\hline $7^{\text {th }}$ Floor & Nov 22, 1993 & $\begin{array}{l}\text { Nov 29, } 1993- \\
\text { Dec 06, } 1993\end{array}$ & $\begin{array}{l}\text { Jan 24, } 1994 \text { - } \\
\text { Mar 01, } 1994\end{array}$ & $\begin{array}{l}\text { Apr } 25,1994- \\
\text { May } 02,1994\end{array}$ & May 02, 1994 & $\begin{array}{l}\text { Aug 30, } 1994 \text { - } \\
\text { Sep 06, } 1994\end{array}$ \\
\hline $8^{\text {th }}$ Floor & Nov 22, 1993 & $\begin{array}{l}\text { Dec 13, } 1994 \text { - } \\
\text { Dec 16, } 1994\end{array}$ & $\begin{array}{l}\text { Feb 08, } 1994 \text { - } \\
\text { Mar 13, } 1994\end{array}$ & $\begin{array}{l}\text { May } 09,1994 \text { - } \\
\text { May } 16,1994\end{array}$ & May 09, 1994 & $\begin{array}{l}\text { Aug 23, } 1994- \\
\text { Aug 30, } 1994\end{array}$ \\
\hline $9^{\text {th }}$ Floor & Nov 22, 1993 & $\begin{array}{l}\text { Dec 13, } 1994 \text { - } \\
\text { Dec 16, } 1994\end{array}$ & $\begin{array}{l}\text { Feb 23, } 1994- \\
\text { Mar 29, } 1994\end{array}$ & $\begin{array}{l}\text { May 09, } 1994 \text { - } \\
\text { May 16, } 1994\end{array}$ & May 23, 1994 & $\begin{array}{l}\text { Aug 23, } 1994- \\
\text { Aug 30, } 1994\end{array}$ \\
\hline $10^{\text {th }}$ Floor & Nov 22,1993 & $\begin{array}{l}\text { Dec 13, } 1994 \text { - } \\
\text { Dec 16, } 1994\end{array}$ & $\begin{array}{l}\text { Mar 09, } 1994 \text { - } \\
\text { Apr 12, } 1994\end{array}$ & $\begin{array}{l}\text { May 16, } 1994 \text { - } \\
\text { May 23, } 1994\end{array}$ & Jun 06, 1994 & $\begin{array}{l}\text { Aug 23, } 1994 \text { - } \\
\text { Aug 30, } 1994\end{array}$ \\
\hline
\end{tabular}

Table 6 - Construction and IAQ Test Schedule 
The following is a list of the measurements performed during each phase. Measurements were performed according to the schedule in Table 6 with the exception of radon. Radon was measured in all eleven zones, inside the underground parking garage, and outside over two three-day periods: July 11 through 14, 1994 and September 20 through 22, 1994, for Phases 2 and 3 respectively.

Phase 1: Interior Build-out Complete

Ventilation System Parameters

Outdoor airflow rate

Pressure relationships

Ventilation system inspection

Pollutant Measurements

Total Volatile Organic Compounds

Particulates

Formaldehyde

Thermal Comfort

Temperature

Relative Humidity

Phase 2: Furniture Installation Complete (Ready for Occupancy)

Ventilation System Parameters

Outdoor airflow rate

Pressure relationships

Pollutant Measurements

Total Volatile Organic Compounds

Particulates

Formaldehyde

Radon

Carbon Monoxide

Thermal Comfort

Temperature

Relative Humidity

Operative Temperature

Phase 3: After Occupancy

Ventilation System Parameters

Outdoor airflow rate

Pressure relationships

Pollutant Measurements

Total Volatile Organic Compounds

Particulates

Formaldehyde

Radon

Carbon Monoxide

Carbon Dioxide

Thermal Comfort

Temperature

Relative Humidity

Operative Temperature 


\section{Measurement Equipment and Techniques}

This section gives a brief description of the test methods and equipment that was used for monitoring each of the indoor environmental parameters. An uncertainty analysis was performed for each measurement procedure based on the uncertainties of the measurement devices and the propagation of uncertainty involved in performing calculations with the measured values. Unless stated otherwise, these uncertainties are reported as the combined standard uncertainty which is the estimated standard deviation of the result obtained by combining the standard uncertainties (estimated standard deviations) of each parameter used to determine the result as described in Reference 21. The standard uncertainties of measurement parameters were obtained from calibrations of measurement equipment and from accuracies quoted by equipment manufacturers.

\section{Ventilation Performance}

Outdoor Airflow Rate - Outdoor airflow rates to each zone were measured directly for all zones but the daycare center. Due to the configuration of the outdoor air intake duct serving the daycare center mechanical room, the outdoor air delivery rate to the daycare center had to be measured indirectly. The direct method entails performing a velocity traverse of the outdoor air delivery duct serving each zone with a hot-wire anemometer. The average velocity is then multiplied by the cross sectional area of the duct at the traverse location to obtain the airflow rate. The indirect method or multiplicative method involves the measurement of the supply airflow rate and the percent outdoor air of the supply airstream of each air handler serving the zone. The supply airflow rate and the percent outdoor air intake rate are then multiplied together to obtain the outdoor airflow rate [22].

For the daycare center, the supply airflow rate was determined using a hot-wire traverse of the supply duct, and the percent outdoor air intake rate was determined using sulfur hexafluoride $\left(\mathrm{SF}_{6}\right)$ as a tracer gas. Tracer gas was injected into the supply airstream of the air handler, allowed to mix within the space for approximately twenty minutes, and then three sets of samples of the supply, return, and outdoor air were taken at ten minute intervals. The tracer gas concentrations of these samples, $\mathrm{C}_{\text {supply }}, \mathrm{C}_{\text {return }}$, and $\mathrm{C}_{\text {outdoor }}$ were then used to calculate the percentage of outdoor air in the supply air using Equation 1 for each set of measurements, and the average of the three calculated values of percent outdoor air was determined.

$$
\text { Percent Outdoor Air }=\left(C_{\text {return }}-C_{\text {supply }}\right) /\left(C_{\text {return }}-C_{\text {outdoor }}\right)
$$

Pressure Relationships between Zones - Pressure relationships between zones were evaluated using smoke tubes to establish the direction of airflow between zones. Prior to occupancy, the pressure relationships of each floor and the parking garage to the stair and elevator shafts were monitored. During the post-occupancy testing phase, the relationships between special zones (restrooms and darkrooms) and the occupied space were also monitored. 


\section{$\underline{\text { Pollutants }}$}

Carbon Dioxide - Carbon dioxide concentration was measured using portable monitors based on non-dispersive infrared absorption. Samples were taken throughout the occupied space of each zone and from the outdoor air. Because $\mathrm{CO}_{2}$ is generated by building occupants, it was only sampled after the zones were occupied during Phase 3.

Carbon Monoxide - Carbon monoxide concentrations were measured using a portable electrochemical analyzer with a built-in pump. Samples were collected at several locations within each zone, in the parking garage, and from the outdoor air using the portable monitor. An automated sampling system which utilized a non-dispersive infrared carbon monoxide monitor was used to monitor carbon monoxide concentrations in the daycare center and the garage.

Formaldehyde - Formaldehyde levels were measured using passive samplers which determine an average concentration over a period of five to seven days. The samplers consist of a glass vial with a sodium bisulfite-treated filter on the bottom. At the beginning of the test period the cap was removed from the vial at the test site, and the formaldehyde was absorbed by the treated filter during the sampling period. At the end of the test period the cap was placed back onto the vial, and the vial was sent to a commercial laboratory for analysis. Samples were taken in one or two locations in the open office space of each zone, including some spaces with a high loading of pressed-wood products such as conference rooms, as well as in the intake plenum of the main outdoor air intake fans.

Particulates - Particulate sampling was performed using a respirable aerosol mass monitor based on a piezoelectric balance, which collects particulates from $0.01 \mu \mathrm{m}$ to $10 \mu \mathrm{m}$ in diameter. Nonrespirable particles (diameter greater than $10 \mu \mathrm{m}$ ) are separated from the respirable particles which collect on a quartz crystal sensor. This sensor determines the concentration of particulates collected in units of $\mathrm{mg} / \mathrm{m}^{3}$. Short term samples (5 minutes) were collected at several locations in each zone.

Radon - Radon was sampled using activated charcoal canisters. These canisters were used to obtain average radon concentrations over a three day period. The canisters were placed at the sample locations and opened to expose the activated charcoal. After a period of three days, they were resealed and sent to a commercial laboratory for analysis. Results were provided in units of $\mathrm{pCi} / \mathrm{L}$. Samples were taken on all levels of the building including the garage levels where the foundation is in contact with the surrounding soil and outdoors. Radon measurements were performed simultaneously throughout the entire building during two 3-day sampling periods.

Volatile Organic Compounds - Samples were collected using a portable pump to draw air from the sample location through a tube (trap) filled with Tenax ${ }^{\circledR}$ sorbent $(0.5 \mathrm{~g}$ of $35 / 60$ mesh of 2,6-diphenyloxide) which absorbs VOCs from the air. Two samples were collected at each sample location; one one-liter and one two-liter sample volume. The samples were then analyzed with a gas chromatograph connected to a mass spectrometer (GCMS) with a mass selective detector (MSD). The concentration of TVOCs was determined from a combined response of all organic compounds found in the sample, having retention times between those of methylene chloride and n-tetradecane, and compared to a deuterated toluene standard to determine the TVOC concentration in $\mu \mathrm{g} / \mathrm{m}^{3}$. 


\section{Thermal Comfort}

Temperature, Relative Humidity, and Operative Temperature - Temperature and relative humidity were measured using an electronic hand-held sensor, and operative temperature was measured using a thermal comfort meter which was specifically designed to determine the operative temperature among other thermal comfort parameters. Measurements were performed for occupants in the standing position, and the local effects of thermal discomfort, such as drafts, were not measured. These environmental parameters were measured in several locations throughout the occupied space of each zone. The temperature and relative humidity were also measured outdoors. For the occupied phase of measurements, these thermal comfort parameters were converted to PPD (predicted percent dissatisfied) using the methodology in ISO Standard 7730-1984 [17].

\section{Measurement Results}

This section presents the results of all three phases of measurements. While the data was used to evaluate the indoor environment at each of the three phases, it is important to note that they only provide information for the point in time at which the measurements were performed. Due to the dynamic nature of some contaminant sources and ventilation system operation, contaminant concentrations can vary significantly from day-to-day and even within the same day.

\section{Outdoor Airflow Rate}

The results of the outdoor air intake rate measurements for each zone of the building are presented in Table 7 along with the design outdoor air intake rate for each zone. Because the outdoor air handlers shut down due to extremely cold outdoor air temperatures and an outdoor air preheat control system which was not yet functioning properly, outdoor airflow rates to some of the zones could not be measured during Phase 1. During Phase 2, the outdoor air intake damper serving the auditorium was closed.

Outdoor air intake rates to each zone were measured twice during the week in which the other environmental parameters were monitored. The results presented in Table 7 are the averages of the two measurements for each zone. The standard deviation of each pair of measurements was within $10 \%$ of the average, and most were less than $5 \%$. The outdoor airflow rates presented in Table 7 include only the airflow rate through the outdoor air intake ducts and do not include the outdoor air leakage through the closed make-up air dampers [see Figure 1]. Although difficult to measure, this leakage through the make-up air dampers appeared to be on the order of $20 \%$ of the outdoor air flow rate through the intake ducts. In most cases the outdoor air intake rate to each zone was greater than the design outdoor air intake rate with the exception of the fourth, fifth and sixth floors. The fourth floor has a higher design intake rate than the others, because it contains a special operations center which was designed to handle a higher peak occupancy during critical situations. The fifth and sixth floor outdoor air intake rates were below design because an outdoor air intake damper serving one of the air handlers on each floor was closed due to broken actuators.

The combined standard uncertainties of the outdoor airflow rates measured in the intake ducts were on the order of $2 \%$ of the indicated values. This uncertainty is based on the manufacturer's stated accuracy of the hot-wire anemometers used to perform the airflow measurements ( 2.5 percent 
of the reading plus $0.05 \mathrm{~m} / \mathrm{s}$ ) and the propagation of uncertainty in calculating the outdoor airflow rate from the average velocity and the cross sectional area of the duct.

\begin{tabular}{|l|c|c|c|c|}
\hline \multirow{2}{*}{ Zone } & \multicolumn{4}{|c|}{ Outdoor Air Intake* [L/s] } \\
\cline { 2 - 5 } & Design & Phase 1 & Phase 2 & Phase 3 \\
\hline Auditorium & 1,628 & -- & 80 & 1,930 \\
Daycare Center & 708 & 830 & 1,110 & 780 \\
2nd Floor & 1,558 & -- & 2,040 & 2,010 \\
3rd Floor & 1,558 & -- & 2,230 & 2,250 \\
4th Floor & 3,210 & 2,100 & 1,810 & 1,780 \\
5th Floor & 1,558 & 2,450 & 1,070 & 1,130 \\
6th Floor & 1,558 & 1,720 & 1,420 & 1,260 \\
7th Floor & 1,558 & 3,190 & 2,400 & 2,310 \\
8th Floor & 1,558 & 2,210 & 2,215 & 2,160 \\
9th Floor & 1,558 & 2,180 & 2,110 & 2,050 \\
10th Floor & 1,558 & 2,270 & 2,210 & 2,210 \\
\hline
\end{tabular}

* OA through Intake duct only

Table 7 - Summary of Outdoor Air Intake Measurements

The outdoor air intake rates presented in Table 7 were used to calculate the per person outdoor air intake rates that are presented in Table 8. Occupant rates for these calculations were obtained from space-use plans for the building. The project reference value for the outdoor air intake rates per person is $10 \mathrm{~L} / \mathrm{s}$ per person, based on the recommendation in ASHRAE Standard 62-1989 for office space. The ASHRAE standard recommends $8 \mathrm{~L} / \mathrm{s}$ per person for auditoriums and for daycare centers (classrooms). As seen in Table 8, the recommended ventilation rates given by ASHRAE were met in all zones except the auditorium and sixth floor. Presumably, when the sixth floor damper is repaired, the outdoor air intake rate for this floor will meet the project reference value.

\begin{tabular}{|l|c|}
\hline \multicolumn{1}{|c|}{ Zone } & $\begin{array}{c}\text { Outdoor Air Intake } \\
\text { [L/s per person] }\end{array}$ \\
\hline Auditorium & 6 \\
Daycare Center & 8 \\
2nd Floor & 23 \\
3rd Floor & 25 \\
4th Floor & 12 \\
5th Floor & 13 \\
6th Floor & 7 \\
7th Floor & 13 \\
8th Floor & 11 \\
9th Floor & 10 \\
10th Floor & 11 \\
\hline
\end{tabular}

Table 8 - Outdoor Airflow Rates per Person (Phase 3) 


\section{Pressure Relationships between Zones}

Smoke tests were performed during all three phases of Task 3. During these tests, the direction of airflow between the occupied space and the main shafts (stairs and elevators) of the building was tested on each level of the building. Smoke tests were performed on the same days as the pollutant concentrations were measured. The results are depicted graphically in Figure 2. This figure is a schematic of the major zones of the building and does not depict all of the flow paths and interconnections of the major zones of the building. The dark arrows indicate the dominant direction of airflow. The lighter arrow indicates an airflow direction that was observed on one occasion between the P1 garage level and the auditorium. The light gray vertical lines represent openings between zones.

As seen in Figure 2, air flowed from the occupied space into the stair and elevator shafts on floors 2 through 10. On the first floor, air flowed from the elevator shafts and stairways into the occupied space. On all parking levels served by the elevator (P1 - P4), air flowed from the elevator shafts into the parking garages via the elevator lobbies (elevator lobbies not shown). The daycare center was positively pressurized relative to the P1-level garage and the outdoors, i.e., air flowed from the daycare center through the elevator lobby and into the garage. Also, air flowed out of the building at the loading dock.

During Phase 3 the direction of airflow between the office space and other special-use areas such as restrooms and darkrooms was checked. All of the restrooms (Floors $2-10$ ) and the darkrooms on the sixth floor were negatively pressurized relative to the occupied space, indicating the exhaust systems serving these areas were providing depressurization of these spaces as intended by design and required by the BOCA Mechanical Code.

The pressure relationships between the occupied zones of the building during all phases of testing were such that a pollutant source in one occupied zone would have a minimal (if any) impact on the others. Garage exhaust fans were running during the measurements, which appears to be the main reason for the tendency of air to flow from the occupiable space of the upper floors $(2-10)$ into the stair and elevator shafts and from the shafts into the garage (via the elevator lobbies) on the garage levels (P1 - P4).

The first floor mechanical systems were not yet installed nor had the interior build-out been started on this floor during Phase 3 measurements. Therefore, it is unclear how the ventilation system of the first floor will affect the airflow patterns in the rest of the building. During the three phases of measurements, air was flowing into the first floor, which would be a desirable condition while this floor is under construction. 


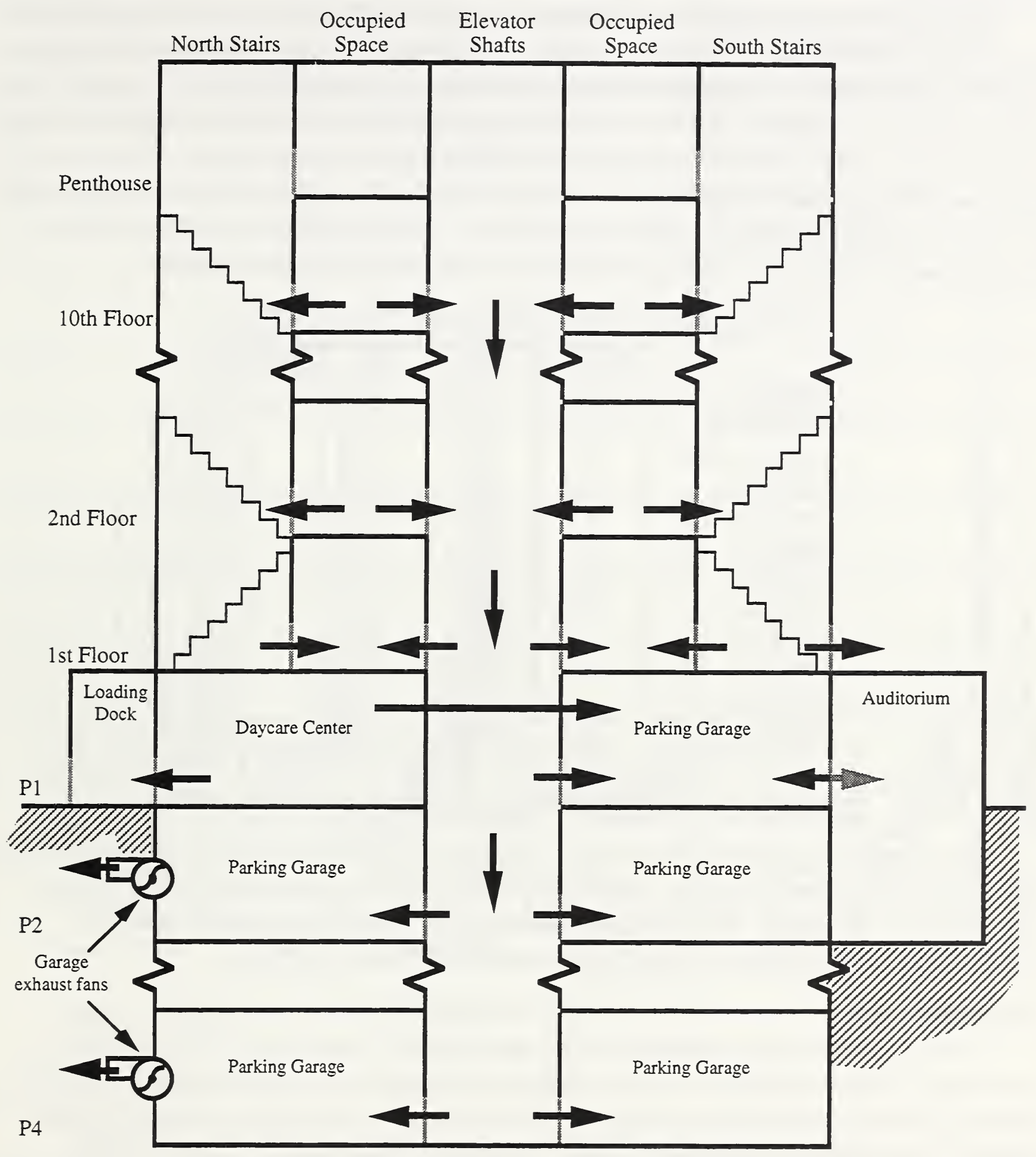

Figure 2 - Summary of Pressure Relationships between Zones (Smoke Tests) 


\section{Carbon Dioxide}

Carbon dioxide measurements were performed only during Phase 3 because this was the only phase during which the zones were to be occupied. Measurements were performed in four to six locations in each zone on a single day during the peak hours of occupancy (10 a.m. to 4 p.m.). These measurements are summarized in Table 9 as the average, maximum, minimum and standard deviation of the measured concentrations in units of parts per million ( $\mathrm{ppm}$ ) for each of the eleven zones and the outdoor air. The average concentrations in each zone are below the project reference value of 1000 $\mathrm{ppm}$. However, this level was exceeded on the north side of the sixth floor because the outdoor air intake damper serving this side of the sixth floor was closed due to a broken actuator.

\begin{tabular}{|l|r|r|r|r|}
\hline \multirow{2}{*}{ Zone } & \multicolumn{4}{|c|}{ Carbon Dioxide Concentration [ppm] } \\
\cline { 2 - 5 } & Average & Max & Min & Std Dev \\
\hline Outdoor & 315 & 329 & 303 & 12 \\
\hline Auditorium & 362 & 365 & 359 & 4 \\
Daycare Center & 678 & 732 & 644 & 38 \\
2nd Floor & 502 & 542 & 469 & 29 \\
3rd Floor & 619 & 674 & 560 & 52 \\
4th Floor & 691 & 784 & 638 & 60 \\
5th Floor & 624 & 704 & 557 & 74 \\
6th Floor & 830 & 1,016 & 562 & 186 \\
7th Floor & 653 & 689 & 631 & 27 \\
8th Floor & 686 & 703 & 652 & 20 \\
9th Floor & 660 & 719 & 603 & 51 \\
10th Floor & 620 & 654 & 561 & 52 \\
\hline
\end{tabular}

Table 9 - Summary of Carbon Dioxide Measurements (Phase 3)

The uncertainty associated with the carbon dioxide measurements is based on calibrations of the $\mathrm{CO}_{2}$ monitor using calibration gases. Based on the $95 \%$ confidence interval estimate for these calibrations, the uncertainty of the measured concentrations ranged from about $\pm 5 \mathrm{ppm}$ for concentrations of $350 \mathrm{ppm}$ to $\pm 15 \mathrm{ppm}$ for concentrations of about $1000 \mathrm{ppm}$.

\section{Carbon Monoxide}

Carbon monoxide concentrations were measured during Phase 2 and 3 of Task 3 . These measurements were performed in several locations in each zone during various times of the day as well as in the garage and outdoors. Each zone was monitored on a single day during each phase. All interior $\mathrm{CO}$ concentrations were below $2 \mathrm{ppm}$, well below project reference value of $10 \mathrm{ppm}$.

Outdoor concentrations were measured on the roof of the building near the outdoor air intake grill and were below the minimum detectable limit of the monitor $(0.5 \mathrm{ppm})$.

Carbon monoxide was also monitored continuously in the daycare center and the parking garage on the same level as the daycare center using an automated monitoring system. These measurements were performed due to special concerns on the part of the building management. The parking garage is a potential source of carbon monoxide for the entire building, but the daycare center is separated 
from the garage only by an elevator lobby. A plot of six days of data is shown in Figure 3. This figure shows that even though the $\mathrm{CO}$ concentrations in the garage reached levels above $8 \mathrm{ppm}$, the $\mathrm{CO}$ concentrations in the daycare center remained below $2 \mathrm{ppm}$ and usually below $1 \mathrm{ppm}$. The low concentrations in the daycare center were due to the negative pressure in the garage relative to the daycare center as demonstrated by smoke tests.

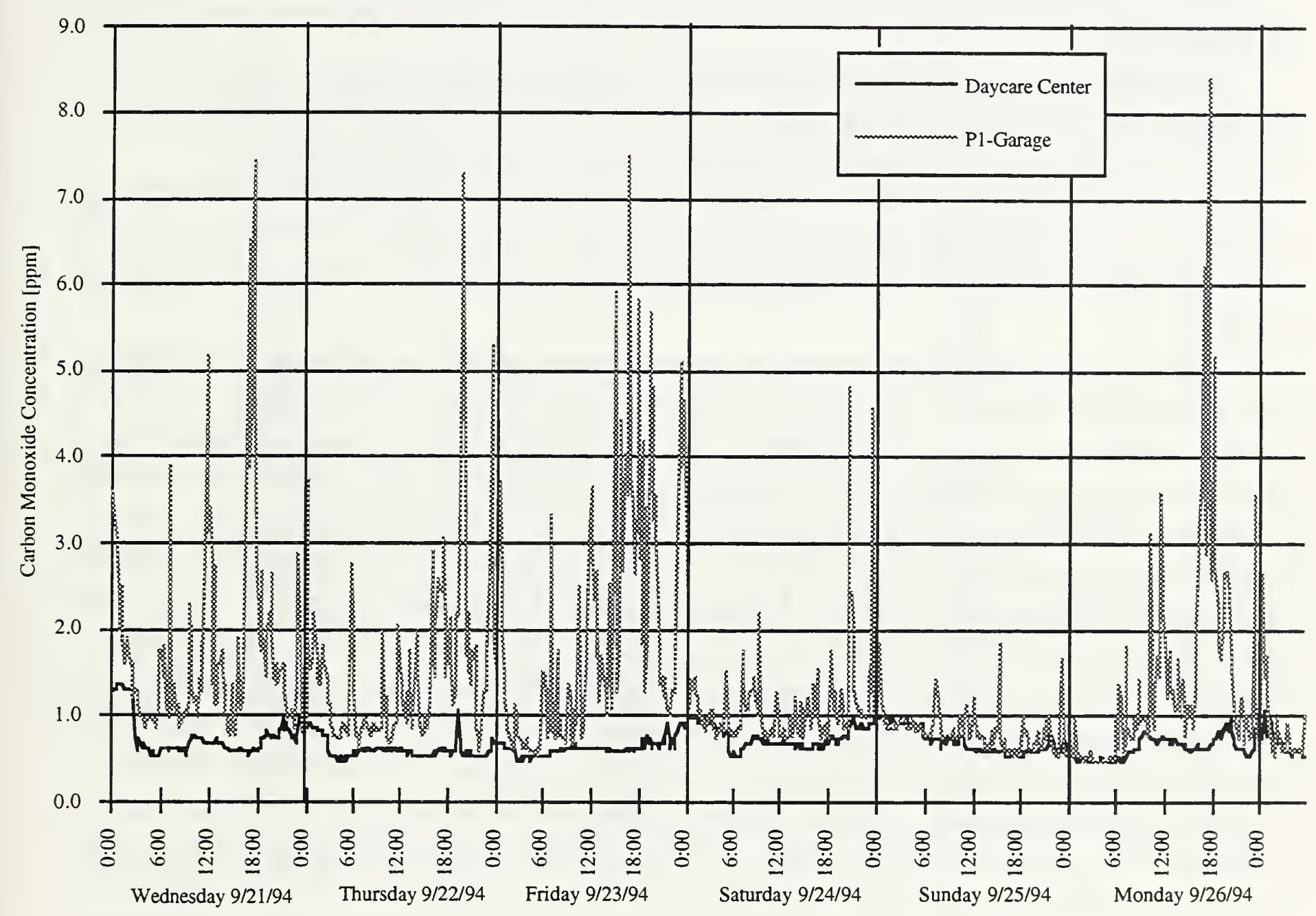

Figure 3 - Carbon Monoxide Concentrations in the Daycare Center and Parking Garage 
The uncertainty associated with the carbon monoxide measurements is based on calibrations of the $\mathrm{CO}$ monitors using calibration gases. A 95\% confidence interval estimate was determined for the calibrations of both the hand-held and automated measurement devices. Based on the $95 \%$ confidence interval estimate, the uncertainties of the concentrations measured using the hand-held monitor were about $\pm 1 \mathrm{ppm}$ and about $\pm 2 \mathrm{ppm}$ for the automated monitor.

\section{Formaldehyde}

Formaldehyde measurements were performed in all three phases of Task 3. These measurements were performed using passive monitors which were installed for a period of seven days in each of the eleven zones and in the outdoor air. The results of the formaldehyde measurements are shown in Table 10. Generally, the monitors were hung from the ceiling in the open office space in either the north or south end of the building; some monitors were deployed in special use rooms such as conference rooms that contained a higher than average loading of pressed-wood products.

In all three phases of measurements, the reported formaldehyde concentrations in the fourth through tenth floor zones were at or below the project reference value of $0.05 \mathrm{ppm}$ and very close to the concentrations measured in the outdoor air. Slightly higher levels were recorded during Phase 2 in the daycare center, auditorium and in the library and conference room of the second floor. While the reasons for these slightly elevated levels are not known for certain, the daycare center contains wood accents and pressed-wood furniture that could be a source of formaldehyde; this is also the case for the library. The conference room on the second floor was being used as temporary storage of new chairs. During Phase 2, the outdoor air intake damper to the auditorium was closed, which may account for the above-average formaldehyde concentrations in the auditorium during this phase. The concentrations measured in the auditorium during Phase 3, when the outdoor air intake damper was open, were below $0.05 \mathrm{ppm}$. At the time of the Phase 3 measurements, the auditorium was not complete and did not have any furniture installed. Therefore the measurements performed were not indicative of the expected furniture loading. The highest formaldehyde levels (approximately 0.10 ppm) were measured during Phase 3 in the Hearing Room on the third floor. This room contains a relatively high loading of pressed-wood furniture and accents to which these levels may be attributed. While these levels are above the project reference value of $0.05 \mathrm{ppm}$, they are just bordering on the level of $0.1 \mathrm{ppm}$ that is considered to be of concern by the World Health Organization (see Table 4).

The uncertainty in the formaldehyde samples was estimated based on the analysis of duplicate measurements (samples taken in the same location at the same time). It was first determined that within-duplicate precision appeared to be similar for each pair of measurements. By pooling together all of the duplicate samples, a 95\% confidence interval estimate was determined for all of the samples to be approximately $\pm 0.01 \mathrm{ppm}$. 


\begin{tabular}{|c|c|c|c|c|c|c|}
\hline \multirow{3}{*}{ Zone } & \multicolumn{6}{|c|}{ Formaldehyde Concentration [ppm] } \\
\hline & \multicolumn{2}{|c|}{ Phase 1} & \multicolumn{2}{|c|}{$\begin{array}{r}\text { Phase 2 } \\
\end{array}$} & \multicolumn{2}{|l|}{ Phase 3} \\
\hline & Location & [ppm] & Location & [ppm] & Location & [ppm] \\
\hline Daycare Center & Infant Area & 0.02 & $\begin{array}{l}\text { Infant Area } \\
\text { Infant Area }\end{array}$ & $\begin{array}{l}0.06 \\
0.08\end{array}$ & $\begin{array}{l}\text { Infant Area } \\
\text { Reception } \\
\text { Room 5 }\end{array}$ & $\begin{array}{l}0.05 \\
0.06 \\
0.06\end{array}$ \\
\hline Auditorium & -- & -- & & $\begin{array}{l}0.07 \\
0.07\end{array}$ & & $\begin{array}{l}0.02 \\
0.02 \\
0.03 \\
\end{array}$ \\
\hline 2nd Floor & -- & -- & \begin{tabular}{|l|} 
Library \\
South \\
Conference Room
\end{tabular} & $\begin{array}{l}0.07 \\
0.05 \\
0.09\end{array}$ & $\begin{array}{l}\text { Library } \\
\text { South }\end{array}$ & $\begin{array}{l}0.05 \\
0.03\end{array}$ \\
\hline 3rd Floor & $\begin{array}{l}\text { Hearing Room } \\
\text { South }\end{array}$ & $\begin{array}{l}0.03 \\
0.02\end{array}$ & $\begin{array}{l}\text { South } \\
\text { Hearing Room }\end{array}$ & $\begin{array}{c}0.04 \\
--\end{array}$ & $\begin{array}{l}\text { Hearing Room } \\
\text { Hearing Room } \\
\text { ILC }\end{array}$ & $\begin{array}{l}0.10 \\
0.09 \\
0.05\end{array}$ \\
\hline 4th Floor & $\begin{array}{l}\text { South } \\
\text { North }\end{array}$ & $\begin{array}{l}0.03 \\
0.03\end{array}$ & $\begin{array}{l}\text { Operations Center } \\
\text { South }\end{array}$ & $\begin{array}{l}0.04 \\
0.04\end{array}$ & $\begin{array}{l}\text { Operations Center } \\
\text { South } \\
\text { North }\end{array}$ & $\begin{array}{l}0.03 \\
0.04 \\
0.05\end{array}$ \\
\hline 5th Floor & $\begin{array}{l}\text { South } \\
\text { South } \\
\text { North }\end{array}$ & $\begin{array}{l}0.03 \\
0.02 \\
0.01\end{array}$ & $\begin{array}{l}\text { South } \\
\text { South } \\
\text { North }\end{array}$ & $\begin{array}{l}0.03 \\
0.04 \\
0.02\end{array}$ & $\begin{array}{l}\text { South } \\
\text { North }\end{array}$ & $\begin{array}{l}0.04 \\
0.02\end{array}$ \\
\hline 6th Floor & $\begin{array}{l}\text { South } \\
\text { North } \\
\text { North }\end{array}$ & $\begin{array}{l}0.02 \\
0.02 \\
0.03\end{array}$ & $\begin{array}{l}\text { North } \\
\text { Conference Room }\end{array}$ & $\begin{array}{l}0.04 \\
0.03\end{array}$ & $\begin{array}{l}\text { South } \\
\text { North }\end{array}$ & $\begin{array}{l}0.04 \\
0.04\end{array}$ \\
\hline 7 th Floor & $\begin{array}{l}\text { South } \\
\text { North }\end{array}$ & $\begin{array}{l}0.03 \\
0.03\end{array}$ & \begin{tabular}{|l|} 
North \\
North \\
Conference Room
\end{tabular} & $\begin{array}{l}0.04 \\
0.04 \\
0.03 \\
\end{array}$ & \begin{tabular}{|l|} 
North \\
North \\
Conference Room
\end{tabular} & $\begin{array}{l}0.04 \\
0.04 \\
0.04 \\
\end{array}$ \\
\hline 8th Floor & \begin{tabular}{|l} 
South \\
North
\end{tabular} & $\begin{array}{l}0.05 \\
0.04\end{array}$ & $\begin{array}{l}\text { North } \\
\text { Conference Room }\end{array}$ & $\begin{array}{l}0.03 \\
0.05\end{array}$ & \begin{tabular}{|l} 
South \\
North
\end{tabular} & $\begin{array}{l}0.04 \\
0.04\end{array}$ \\
\hline 9th Floor & $\begin{array}{l}\text { South } \\
\text { North }\end{array}$ & $\begin{array}{l}0.04 \\
0.04\end{array}$ & $\begin{array}{l}\text { North } \\
\text { Conference Room }\end{array}$ & $\begin{array}{l}0.03 \\
0.02\end{array}$ & $\begin{array}{l}\text { North } \\
\text { Conference Room }\end{array}$ & $\begin{array}{l}0.04 \\
0.05\end{array}$ \\
\hline 10th Floor & $\begin{array}{l}\text { South } \\
\text { North }\end{array}$ & $\begin{array}{l}0.05 \\
0.05\end{array}$ & \begin{tabular}{l|} 
North \\
North \\
Conference Room
\end{tabular} & $\begin{array}{l}0.04 \\
0.02 \\
0.04\end{array}$ & \begin{tabular}{|l|} 
North \\
North \\
Conference Room
\end{tabular} & $\begin{array}{l}0.04 \\
0.01 \\
0.04\end{array}$ \\
\hline Outdoor Air, Al & gerage (Min-Max) & $.04(.02-.04)$ & & $.02(.01-.04)$ & & $.03(.01-.05)$ \\
\hline
\end{tabular}

Table 10 - Formaldehyde Measurements 


\section{Particulates}

Respirable particulate measurements were performed in all three phases of Task 3. Several measurements (between 2 and 6) were taken throughout each of the eleven zones during each phase; the outdoor air concentration was also monitored during Phases 2 and 3 . The results of the particulate measurements are shown in Table 11 in terms of the average and standard deviation (Std Dev) of each set of measurements taken in each zone. Generally, the indoor particulate concentrations were below $50 \mu \mathrm{g} / \mathrm{m}^{3}$, which was also the average outdoor concentration, and were well below the project reference value of $150 \mu \mathrm{g} / \mathrm{m}^{3}$. On one day during Phase 1 (unoccupied), levels up to $400 \mu \mathrm{g} / \mathrm{m}^{3}$ were measured in the fourth floor zone. This was attributed to welding being performed on the fourth floor that produced a significant amount of smoke. Even though significant levels existed in the fourth floor zone, the two adjacent zones (Floor 3 and 5) did not exhibit elevated levels because they were positively pressurized relative to the stair and elevator shafts. The uncertainty of these measurements are given by the manufacturer of the mass monitor to be $\pm 10 \mu \mathrm{g} / \mathrm{m}^{3}$ or $10 \%$ of the measured value, which ever is greater.

\begin{tabular}{|l|r|r||r|r||c|c|}
\hline \multirow{3}{*}{ Zone } & \multicolumn{5}{|c|}{ Respirable Particulate Concentration $\left[\mu \mathrm{g} / \mathrm{m}^{3}\right]$} \\
\cline { 2 - 7 } & \multicolumn{2}{|c|}{ Phase 1 } & \multicolumn{2}{|c|}{ Phase 2 } & \multicolumn{2}{c|}{ Phase 3 } \\
\cline { 2 - 7 } & Average & Std Dev & Average & Std Dev & Average & Std Dev \\
\hline \hline Outdoor Air & -- & -- & 54 & 53 & 42 & 42 \\
\hline Auditorium & -- & -- & 49 & 5 & 28 & 1 \\
Daycare Center & 27 & -- & 48 & 12 & 43 & 10 \\
2nd Floor & 21 & 1 & 28 & 3 & 19 & 5 \\
3rd Floor & 12 & 3 & 25 & 3 & 18 & 10 \\
4th Floor & 246 & 140 & - & - & 22 & 4 \\
5th Floor & 26 & 7 & 20 & 11 & 20 & 1 \\
6th Floor & 18 & 5 & 21 & 8 & 23 & 7 \\
7th Floor & 16 & 3 & 22 & 4 & 26 & 7 \\
8th Floor & 11 & 3 & 31 & 8 & 26 & 1 \\
9th Floor & 13 & 1 & 25 & 2 & 20 & 2 \\
10th Floor & 12 & 2 & 20 & 5 & 27 & 5 \\
\hline
\end{tabular}

Table 11 - Summary of Respirable Particulate Measurements

\section{$\underline{\text { Radon }}$}

Radon levels were monitored twice throughout the entire building and in the outdoor air intake plenum for three days near the end of Phases 2 and 3 of Task 3. The results of these measurements are presented in Table 12 along with the average and standard deviation of the indoor concentration (not including garage measurements). The minimum detectable limit of the measurement technique is 0.2 picocuries per liter of air $(\mathrm{pCi} / \mathrm{L})$ and several measurements were less than this limit as indicated in the table $(<0.2)$. All of the measured values were $1.1 \mathrm{pCi} / \mathrm{L}$ or less which is well below the project reference value of $4 \mathrm{pCi} / \mathrm{L}$.

According to the laboratory that performs the analysis on the radon canisters, the uncertainty in the measurements at these levels ( $1 \mathrm{pCi} / \mathrm{L}$ and below) is approximately 100 percent. This implies that 
these values could be anywhere from 0 to $2 \mathrm{pCi} / \mathrm{L}$, which is still below the project reference value. An analysis of the duplicate measurements performed showed that the duplicate results were within the expected levels of agreement as described in Reference 23.

\begin{tabular}{|l|c||l|c|}
\hline \multicolumn{2}{|c|}{ Phase 2 } & \multicolumn{2}{c|}{ Phase 3 } \\
\hline \multicolumn{1}{|c|}{ Location } & {$[\mathrm{pCi} / \mathrm{L}]$} & \multicolumn{1}{|c|}{ Location } & [pCi/L] \\
\hline Outdoor Air & $<0.2$ & Outdoor Air & 0.7 \\
& & & $<0.2$ \\
\hline 10th - North Return & 0.3 & 10th - North Return & 0.5 \\
& & 10th - North & 0.4 \\
\hline 9th - South Return & 0.3 & 9th - South & 0.2 \\
\hline 8th - North Return & 0.3 & 8th - North Return & 0.5 \\
& & 8th - South & 0.7 \\
\hline 7th - South Return & 0.3 & 7th - South Return & 0.3 \\
& & 7th - South & 0.4 \\
\hline 6th - North Return & 0.6 & 6th - North Return & 0.3 \\
& & 6th - North & 0.9 \\
\hline 5th - South Return & 0.4 & 5th - South Return & 0.2 \\
& & 5th - South & 0.3 \\
\hline 4th - North Return & 0.4 & 4th - North Return & 0.9 \\
& 0.4 & 4th - Operations Center & 0.6 \\
\hline 3rd - South Return & 0.4 & 3rd - South Return & 0.4 \\
& & 3rd - Hearing Room & $<0.2$ \\
\hline 2nd - North Return & 0.4 & 2nd - North Return & 0.4 \\
& & 2nd - Library & 0.7 \\
\hline 1st - Exhibition Area & 0.6 & 1st - Exhibition Area & $<0.2$ \\
\hline Daycare - Return & 0.3 & Daycare - Return & 0.6 \\
Daycare - Return & 0.5 & Daycare - Reception & 0.6 \\
Daycare - Infant Area & 0.4 & & \\
\hline Auditorium & 0.4 & Auditorium & 0.4 \\
\hline P1 - Elevator Lobby & 0.2 & P1 - Elevator Lobby & $<0.2$ \\
& & P1 - Garage & 0.4 \\
\hline P2 - Elevator Lobby & 0.2 & P2 - Garage & 0.4 \\
P2 - Elevator Lobby & 0.4 & & \\
\hline P3 - Elevator Lobby & $<0.2$ & P3 - Garage & 0.6 \\
\hline P4 - Elevator Lobby & $<0.2$ & P4 - Elevator Lobby & 0.5 \\
& & P4 - Garage & 0.2 \\
\hline Stoor Average * & 0.4 & P5 - Garage & 1.1 \\
& & P5 - Garage & 0.5 \\
\hline \multirow{2}{*}{ Dtandard Deviation } & 0.1 & P5 - Garage & 0.6 \\
\hline Stoor Average * & 0.5 \\
& Standard Deviation & 0.2 \\
\hline
\end{tabular}

* Does not include garage measurements

Table 12 - Radon Measurements 


\section{Volatile Organic Compounds}

Measurements of volatile organic compounds (VOCs) were performed during all three phases of Task 3. During each phase two samples were taken in the return airstream of one of the air handlers serving the zone being monitored. An outdoor air sample was also taken along with each set of indoor measurements. The results of these measurements are presented in Table 13 as total VOCs (TVOCs) in units of micrograms per cubic meter of air $\left(\mu \mathrm{g} / \mathrm{m}^{3}\right)$. The values reported are the averages of the two samples taken side-by-side at each location. The values presented for the outdoor air are the averages of all the outdoor air samples taken during each phase. The uncertainty in the TVOC samples was estimated based on the analysis of duplicate measurements. It was first determined that within-duplicate precision appeared to be similar for each pair of measurements. By pooling together all of the duplicate samples, a 95\% confidence interval estimate was determined for all of the samples to be approximately $\pm 10 \mu \mathrm{g} / \mathrm{m}^{3}$. This uncertainty indicates that the measurement technique used was repeatable, but it does not account for other sources of measurement error such as inefficiency of the sorbent used to trap the VOCs, the use of a single response factor (deuterated toluene) to calculate the TVOC concentration, or the inability of the analysis method to detect all of the VOCs that were collected on the sorbent material.

\begin{tabular}{|l|r|r|r|}
\hline \multirow{2}{*}{ Zone } & \multicolumn{3}{|c|}{ Total VOC Concentration $\left[\mu \mathrm{g} / \mathrm{m}^{3}\right]$} \\
\cline { 2 - 4 } & Phase 1 & Phase 2 & Phase 3 \\
\hline \hline Outdoor Air & 80 & 20 & 30 \\
\hline Auditorium & - & 940 & 250 \\
Daycare Center & 600 & 490 & 240 \\
2nd Floor & 130 & 340 & 130 \\
3rd Floor & 450 & 400 & 110 \\
4th Floor & 1230 & 310 & 210 \\
5th Floor & 840 & 290 & 190 \\
6th Floor & 530 & 140 & 290 \\
7th Floor & 280 & 290 & 140 \\
8th Floor & 240 & 180 & 180 \\
9th Floor & 340 & 180 & 190 \\
10th Floor & 620 & 180 & 190 \\
\hline
\end{tabular}

Table 13 - Summary of TVOC Measurements

Generally, the TVOC concentrations were well below the project reference value of $1000 \mu \mathrm{g} / \mathrm{m}^{3}$. Only one measurement exceeded the project reference value, and that was on the fourth floor during Phase 1. The fourth and fifth floors were the first zones to be tested, and they had the highest measured TVOC concentrations during Phase 1. Also, the outdoor air intake fans were not running continuously until only the day before the Phase 1 tests began. Throughout Phase 1 the air handling systems did not run continuously because the fire/smoke control systems were being tested and the outdoor air intake preheat system was not functioning properly because it required adjustment. During Phase 2, the auditorium concentration was very close to $1000 \mu \mathrm{g} / \mathrm{m}^{3}$. During this phase, the outdoor air intake damper of the auditorium air handler was closed, and very little outdoor air was being delivered. 
The measured TVOC concentrations tended to decrease with time, and all of the measured values were below $300 \mu \mathrm{g} / \mathrm{m}^{3}$ during the occupied phase (Phase 3). This decrease in average TVOC concentration could be attributed to an increasing outdoor air intake rate (increased dilution of VOCs) and/or a decrease of VOC source strengths over time. As revealed previously in the results of outdoor air intake measurements, the outdoor air intake rate remained fairly constant between Phases 2 and 3 , and it actually decreased in several zones between Phases 1 and 2. This suggests that the TVOC source strength decreased steadily after the base building was complete.

Source strengths were calculated using Equation 2, which is based on the simplifying assumption that the measured TVOC concentrations were at steady state.

$$
S S=\left(C_{e q}-C_{o a}\right) \cdot Q_{o a} / A
$$

Equation 2

$\mathrm{SS}=$ Source strength, $\mathrm{mg} / \mathrm{m}^{2} \cdot \mathrm{hr}$

$\mathrm{C}_{\mathrm{eq}}=$ Indoor TVOC equilibrium concentration, $\mathrm{mg} / \mathrm{m}^{3}$

$\mathrm{C}_{\mathrm{oa}}=$ Outdoor TVOC concentration, $\mathrm{mg} / \mathrm{m}^{3}$

$\mathrm{Q}_{\mathrm{oa}}=$ Outdoor airflow rate into zone, $\mathrm{m}^{3} / \mathrm{hr}$

$\mathrm{A}=$ Floor area of zone, $\mathrm{m}^{2}$

Figure 4 is a plot of TVOC source strengths versus the elapsed time since the interior build-out was complete for all zones but the daycare center and auditorium. The outdoor air intake rates used to calculate the TVOC source strengths only includes outdoor airflow through the intake ducts (presented in Table 7) and not the outdoor air leakage through the closed make-up air dampers. As previously mentioned, this leakage could not be measured reliably but appeared to be on the order of $20 \%$ of the outdoor airflow rate through the intake ducts. Therefore, if this leakage were included in the outdoor airflow rate used in Equation 2, the calculated source strengths would be approximately $20 \%$ greater than those presented in Figure 4.

Building materials and furnishings and occupant related activities (e.g. the use of cleaning products) are potential sources of VOCs. The installation of systems furniture began about 21 days after completion of the interior build-out, and all of the systems furniture was placed in the second through tenth floors 168 days after the interior build-out was complete. If the systems furniture was a significant and long-lasting source of VOCs it would have been indicated by an increase in TVOC source strength after the furniture was installed. Similarly, occupants began moving in approximately 150 days after completion of the interior build-out. However, Figure 4 shows an overall decrease in source strength in all of these zones since the completion of the interior build-out. This is an indication that the major sources of VOCs were related to activities and building materials used during the interior build-out and not to the systems furniture or occupant-related activities. Based on these measurements, it appears that the levels of outdoor air intake provided are adequate for maintaining TVOC levels below the project reference value, assuming the sources of VOCs do not increase significantly, and the measurements performed are representative of typical conditions. 


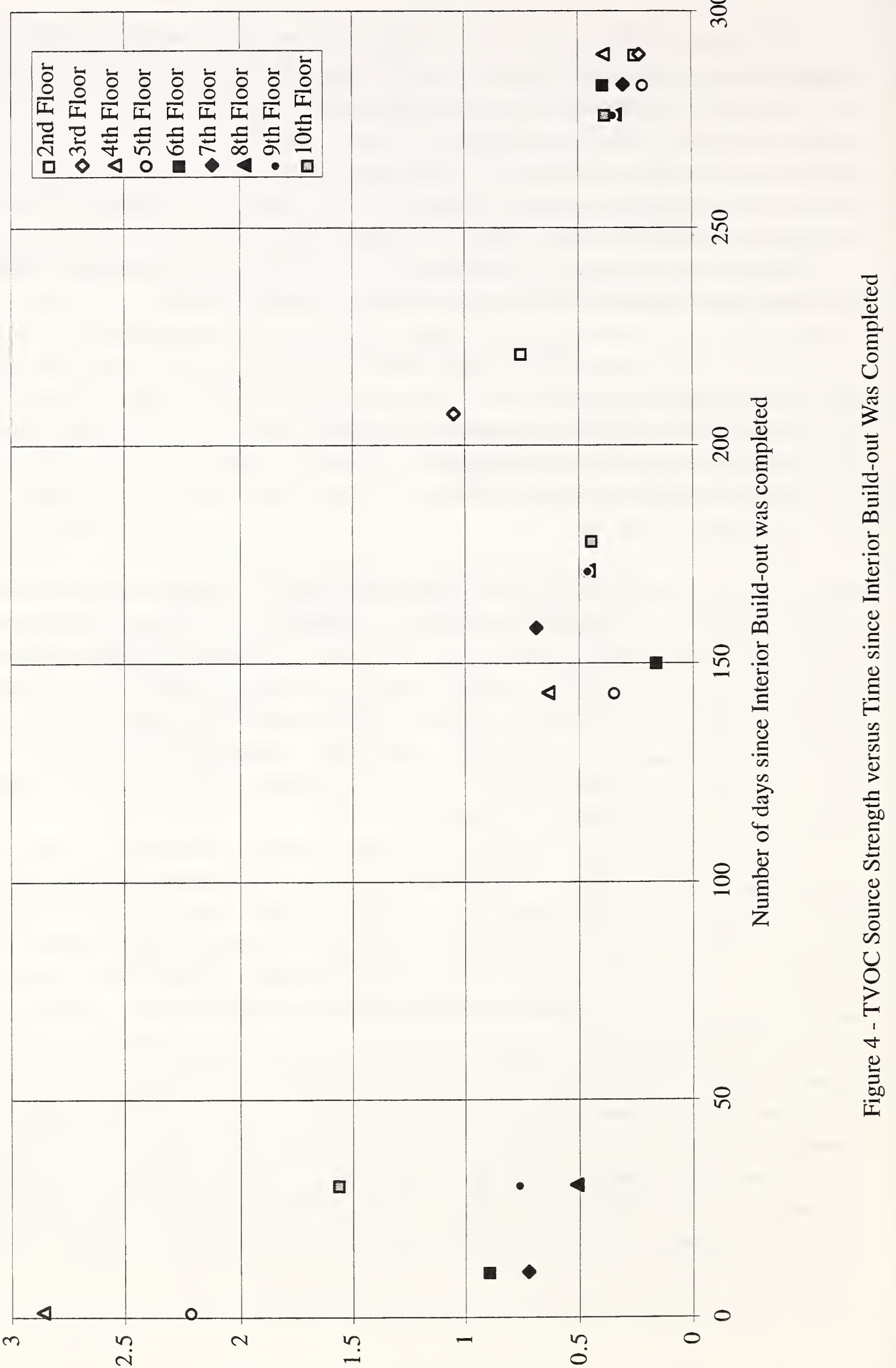

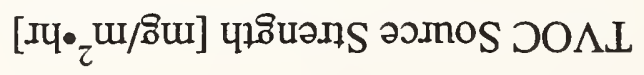




\section{Thermal Comfort}

Several environmental parameters were measured in order to characterize thermal comfort. The parameters measured were temperature $(\mathrm{T})$, percent relative humidity $(\% \mathrm{RH})$, and operative temperature $\left(\mathrm{T}_{\mathrm{op}}\right)$. The results of these measurements in all three phases are presented in Table 14; operative temperature was not measured during Phase 1. The PPD index was only calculated for the occupied phase of measurements, because the thermal load in the building was not representative of occupied conditions during the other two phases of measurements. The values shown in the table are averages for several (2 to 5 ) measurements performed throughout the occupied space of each zone. All three parameters were fairly uniform throughout the zones as demonstrated by the fact that the standard deviations (not shown in table) of measurements performed within each zone were always within $10 \%$ of the average values and usually within $5 \%$.

The temperature was measured in order to characterize the performance of the HVAC system in terms of maintaining the indoor temperature at the design temperature of $24^{\circ} \mathrm{C}\left(75^{\circ} \mathrm{F}\right)$. As seen in Table 14, the average temperature in each of the zones during the occupied phase of measurements (Phase 3) were within $1^{\circ} \mathrm{C}$ of the design temperature of $24^{\circ} \mathrm{C}$ with the exception of the tenth floor which was approximately $2{ }^{\circ} \mathrm{C}$ lower than the design temperature. Phase 3 measurements were performed during the summer months of August and September, indicating the HVAC system is capable of maintaining the design temperature within the occupied space under summer conditions.

The PPD values for Phase 3 presented in Table 14 are based on slightly active office workers (metabolic rate of $81 \mathrm{~W} / \mathrm{m}^{2}$ or $1.4 \mathrm{met}$ ) wearing typical light summer clothing (clothing insulation value of $0.08 \mathrm{~m}^{2} \cdot{ }^{\circ} \mathrm{C} / \mathrm{W}$ ). Based on these assumptions, all 11 zones have PPD values of less than $10 \%$. This is indicative of generally acceptable conditions for thermal comfort.

\begin{tabular}{|l||c|c||c|c|c||c|c|c|c|}
\hline \multicolumn{1}{|c||}{ Location } & \multicolumn{2}{c||}{ Phase 1 } & \multicolumn{3}{c||}{ Phase 2 } & \multicolumn{4}{c|}{ Phase 3 } \\
\cline { 2 - 10 } \cline { 5 - 9 } & $\mathrm{T}\left[{ }^{\circ} \mathrm{C}\right]$ & $\% \mathrm{RH}$ & $\mathrm{T}\left[{ }^{\circ} \mathrm{C}\right]$ & $\% \mathrm{RH}$ & $\mathrm{T}_{\mathrm{op}}\left[{ }^{\circ} \mathrm{C}\right]$ & $\mathrm{T}\left[{ }^{\circ} \mathrm{C}\right]$ & $\% \mathrm{RH}$ & $\mathrm{T}_{\text {op }}\left[{ }^{\circ} \mathrm{C}\right]$ & $\mathrm{PPD}$ \\
\hline \hline Auditorium & -- & -- & 25 & 53 & 25 & 24 & 40 & 23 & 6 \\
Daycare Center & 18 & 15 & 25 & 63 & 26 & 24 & 43 & 24 & 6 \\
2nd Floor & 22 & 9 & 24 & 33 & 24 & 23 & 33 & 23 & 12 \\
3rd Floor & 22 & 11 & 23 & 38 & 23 & 23 & 37 & 23 & 11 \\
4th Floor & 23 & -- & 23 & 35 & 23 & 23 & 44 & 23 & 10 \\
5th Floor & 21 & -- & 22 & 31 & 22 & 23 & 34 & 23 & 12 \\
6th Floor & 23 & 22 & 23 & 20 & 22 & 23 & 36 & 23 & 11 \\
7th Floor & 22 & 23 & 22 & 32 & 22 & 24 & 34 & 23 & 7 \\
8th Floor & 22 & 20 & 22 & 38 & 22 & 24 & 35 & 24 & 7 \\
9th Floor & 22 & 19 & 20 & 41 & 19 & 23 & 35 & 22 & 12 \\
10th Floor & 20 & 14 & 21 & 37 & 21 & 22 & 35 & 22 & 20 \\
\hline Average & 21 & 16 & 23 & 38 & 23 & 23 & 37 & 23 & 10 \\
Std/Avg & $7 \%$ & $31 \%$ & $8 \%$ & $30 \%$ & $8 \%$ & $2 \%$ & $10 \%$ & $2 \%$ & $40 \%$ \\
\hline
\end{tabular}

Table 14 - Summary of Environmental / Thermal Comfort Measurements 


\section{DISCUSSION}

In addition to providing IAQ performance data in a new office building, this commissioning program revealed several issues that could be helpful in planning and carrying out future commissioning efforts. This section discusses some of the lessons learned from this effort, including issues that must be dealt with when implementing a commissioning effort and some of the benefits of this and presumably other IAQ commissioning programs. Recommendations for future IAQ commissioning projects based on the results of this effort are presented, followed by a short discussion of additional issues relevant to future commissioning efforts.

\section{Implementing an IAQ Commissioning Program During Construction}

For a commissioning program to be effective, several issues need to be addressed in planning and implementing the program. These issues are related to conducting the program in a building that is under construction and fall into the following three categories: (1) Logistics and jurisdiction, (2) Impact of construction activities, and (3) Equipment and controls problems.

Logistics and jurisdiction issues are related to the fact that the construction of a new building is a complex process involving many people, and that the responsibility for the building and its systems change hands during the construction process. Given the various groups involved in the design and construction of the building and administering the IAQ commissioning program, it is inevitable that some logistical and jurisdictional issues arise. These issues include access to the building by the IAQ commissioners, a lack of familiarity with the HVAC systems on the part of those operating the mechanical systems, responsibility for utility costs associated with system operation schedules required for commissioning, responsibility for repair of system defects, ability of the commissioning staff to obtain up-to-date system design information and information on the construction schedule, and notification of the IAQ commissioners of construction related to change orders that is taking place.

In implementing an IAQ commissioning program, several issues are likely to arise related to the impact of construction activities. Construction of a commercial building is a complex process with unanticipated changes and problems that result in unscheduled construction activities and the need to modify completed spaces. The IAQ commissioning effort in the NRC building was included in the construction schedule, with one week of IAQ testing scheduled on each floor both after the base building construction was complete and again after the systems furniture was installed. However, last-minute construction activities could not be avoided, and some of these activities interfered with and delayed the IAQ testing. For example, testing and configuring the fire alarm and smoke control systems caused delays of outdoor airflow measurements. Also, some welding was in progress on the fourth floor during the first phase of testing, resulting in high particulate levels. Other IAQ tests were postponed when the penthouse floor was scheduled to be sealed and the building outdoor air intake fan was turned off in anticipation of this activity.

Equipment and controls problems or "bugs" in the HVAC system are not unexpected during the construction and early-occupancy phases of a building, and their early identification is a benefit of commissioning. However, they can interfere with IAQ commissioning tests, and this occurred in the NRC building on several occasions. One of the large outdoor air intake fans in the penthouse had a 
problem with the freeze-status alarm reset during Phase 1 of Task 3 . The freeze-status protects the HVAC equipment from damage due to freezing by turning on a preheating system when the outdoor air temperature gets below freezing. The preheat system is supposed to heat the outdoor air prior to its introduction into the fan system, but that system did not appear to be properly adjusted for one of the outdoor air fans at this stage of construction. This problem repeatedly disrupted the IAQ measurements during Phase 1 and conflicted with the goal of 24-hour ventilation during the IAQ tests. Similarly, some of the outdoor air dampers which controlled the intake to the individual floor mechanical rooms were not operating and remained closed during the tests. Also, in the middle of the testing program, one of the penthouse intake fan motors broke down, postponing the second phase of IAQ testing until the fan was repaired.

While several situations are described that interfered with the commissioning program, such problems are inevitable when working in a building that is under construction. Almost all of these circumstances were resolved early in the project and did not significantly impact the overall commissioning effort.

\section{Benefits of the NRC IAQ Commissioning Program}

In addition to increasing the likelihood of providing an indoor environment in the NRC building that is acceptable in terms of occupant health and comfort, there were other benefits to this IAQ commissioning program. The process of conducting the tests revealed defects with the HVAC system that may not have been identified until later in the construction process or perhaps well into the building occupancy. During the IAQ tests, NIST staff repeatedly checked the ventilation system to make sure it was being operated as required for the testing. They also performed airflow rate measurements as part of the testing. This inspection and attention to the system enabled the identification of a variety of problems that were brought to the attention of the owners, contractors, and NRC well before the building became occupied.

The commissioning effort also identified issues that would need to be addressed later due to changes in the building design. For example, the first floor of the NRC building was originally intended to be leased, commercial space. It was later redesignated for use by NRC, and therefore the space and the ventilation system serving the space had to be redesigned. The first-floor system was not yet installed at the time of the IAQ commissioning. Therefore, all of the airflow rate measurements and evaluations of pressure relationships between zones were made without the first-floor ventilation system in operation. The IAQ commissioning effort identified the fact that these pressure relationships, and the possibility of airflow from the garage into the rest of the building, need to be reassessed once the first-floor ventilation system is operating.

Another benefit of the IAQ commissioning was the ability to address specific issues of concern that arose during construction and early occupancy based on the building layout, specific pollutant sources, and occupant concerns. For example, occupant concern developed over the proximity of the daycare center to the underground parking garage and the possibility of motor vehicle exhaust migrating into the daycare center. This concern was heightened by a highly publicized incident in which a daycare center in another building in the vicinity had to be evacuated due to exhaust fumes from a parking garage. In response to this concern, a real-time carbon monoxide monitoring system 
was installed to simultaneously monitor the garage and the daycare center carbon monoxide concentrations for about two weeks. This monitoring showed no evidence of motor vehicle exhaust migration from the garage into the daycare center.

\section{Recommendations}

Based on the results of the commissioning effort in the NRC building, several recommendations can be made for the planning and implementation of future IAQ commissioning programs. The first recommendation is to start planning the commissioning effort as early as possible, well before the design of the building. The need for an early commitment is true for all building commissioning, not just for indoor air quality commissioning. In fact, IAQ commissioning should ultimately be integrated into an overall building commissioning effort that incorporates the as-installed performance of the building systems. ASHRAE Guideline 1-1989 [1] describes procedures for commissioning HVAC systems and describes the process from pre-design to recommissioning after the space-use and occupancy of a building has changed. Before a building is designed, it is critical that the commitment to commissioning the building be made by defining the responsibilities of the various individuals and organizations involved in the process.

The pre-design commissioning activities should include identifying the logistical needs of the IAQ commissioners in terms of building access, parking, telephones, and the storage of test equipment. The manner in which the ventilation system is to be operated at various stages of building construction and IAQ testing must also be identified, as well as those responsible for operating the ventilation system throughout the construction process. Particular attention must be given to these logistical details at times of transition, for example when the contractors responsible for the base-building construction complete their responsibilities and the next phase of construction begins.

Even though the building construction schedule inevitably changes, specific times must be included in the schedule for IAQ testing. These should be selected in consultation with those doing the IAQ testing to avoid times at which other activities in the building might interfere with the testing. The IAQ testing schedule also needs to be sufficiently flexible to deal with situations in which such confounding activities do occur or in which the ventilation system is not operating as desired. Flexibility of the commissioning program is also important in order to address IAQ concerns that arise during construction or early in the occupancy of the building.

\section{Additional Considerations}

There are three additional considerations that merit discussion with reference to IAQ commissioning: environmental parameters for measurement, contaminant source characterization, and ventilation system operation. Specific guidance in these areas will ultimately be required when developing future IAQ commissioning programs, but the information needed to develop this guidance is not yet available. The environmental parameters that are measured in the program and the reference values to which they are compared are both critical in defining an IAQ commissioning program. The NRC program involved the measurement of several specific airborne contaminants and other environmental parameters, but these are by no means the only contaminants of concern. The concentrations of individual volatile organic compounds and bioaerosols (mold, fungus, etc.) are also important and could have been included in the program at significant additional cost. It is not yet 
clear which parameters are most appropriate for measurement in an IAQ commissioning effort, and, more importantly, what are the most appropriate target values for the measured parameters. The reference values used in the NRC program were based on the limited guidance that is currently available, but more well-founded contaminant concentration limits specific to the indoor environment are needed.

Another aspect of IAQ commissioning that was not addressed in this project is the characterization of the source strengths of the building materials and furnishings used in the building. In the NRC building, material and furnishing selection was already complete when this study was undertaken and did not involve the characterization of pollutant emissions from the office furnishings and other building materials. It is generally accepted that low emitting products should be used whenever possible, and that material selection should be based on careful and thorough consideration of the potential emissions from materials and furnishings. Ideally, this consideration would involve the characterization of emissions from the products prior to and as a basis for their selection [20 and 24]. However, standard test methods do not exist for measuring the emissions from building materials.

Finally, the manner in which the ventilation system is operating during construction can play a role in minimizing the potential for IAQ problems. Assuming that sources will exist inside the building during construction, higher ventilation rates will lead to lower concentrations and less absorption onto interior surfaces. Various recommendations exist for ventilation system operation during construction and immediately following the completion of construction. These recommendations include implementing a building flush-out period, sealing off the ventilation system ductwork, installing a temporary exhaust system, and maintaining specific pressure relationships between particular building zones [20]. The manner in which the ventilation system is to be operated, any temporary arrangements involving building operation and maintenance, as well as any other requirements must be described in detail in the commissioning program plan. However, additional research is needed to define the most appropriate ventilation strategies in more detail and to identify optimal approaches. 


\section{REFERENCES}

[1] ASHRAE. ASHRAE Guideline 1-1989, "Guideline for commissioning of HVAC systems," Atlanta: American Society of Heating, Refrigerating, and Air-conditioning Engineers, Inc., 1989.

[2] Sterling, E.M.; C.W. Collett; S. Turner; and C.C. Downing. "Commissioning to avoid indoor air quality problems," ASHRAE Journal, October 1992, pp.28-32.

[3] Grot, R.A.; A.K. Persily; A.T. Hodgson; and J.M. Daisey. "Environmental evaluation of the Portland East Federal Building preoccupancy and early occupancy results," NISTIR 89-4066, National Institute of Standards and Technology, Gaithersburg, MD, 1989.

[4] Persily, A.K.; W.S. Dols; and S.J. Nabinger. "Environmental evaluation of the Federal Records Center in Overland Missouri," NISTIR 4883, National Institute of Standards and Technology, Gaithersburg, MD, 1992.

[5] The BOCA National Mechanical Code/1987. Building Officials \& Code Administrators International, Inc., Country Club Hills, IL, 1987.

[6] ASHRAE Standard 62-1989. "Ventilation for acceptable air quality," American Society of Heating, Refrigerating, and Air-Conditioning Engineers, Inc., Atlanta, GA, 1989.

[7] Two White Flint North, North Bethesda, Maryland, Volume I ARCHETECTURAL (Specifications for Construction), Prepared by: Dewberry and Davis Corporation, Fairfax, VA, September 12, 1991.

[8] Two White Flint North. North Bethesda, Maryland, Volume II MECHANICAL/ELECTRICAL (Specifications for Construction), Prepared by: The Office of Lee Kendrick, Fairfax, VA, September 12, 1991.

[9] Two White Flint North, North Bethesda, Maryland, SPECIFICATIONS, Prepared by: Leland D. Eisenhower, LTD., McLean, VA, February, 1993.

[10] Two White Flint North. North Bethesda, Maryland, ARCHITECTURAL DRAWINGS, D/B/I, Washington, D.C., Addendum May 4, 1993.

[11] Two White Flint North, North Bethesda, Maryland, SPACE PLAN DRAWINGS, D/B/I, Washington, D.C., August 31, 1992.

[12] Code of Federal Regulations, Title 40 Part 50 (40 CFR50), "National primary and secondary ambient air quality standards," U.S. Environmental Protection Agency, as amended July 1, 1987.

[13] World Health Organization, Report on a WHO meeting, August 21-24, 1984, "Indoor air quality research," EURO Reports and Studies 103, Regional Office for Europe, Copenhagen, Denmark, 1984.

[14] Code of Federal Regulations, Title 24, Part 3280.308, "Formaldehyde emissions control for manufactured homes," U.S. Department of Housing and Urban Development, April 1, 1988.

[15] Mølhave, L. "Volatile Organic Compounds, Indoor Air Quality and Health," Indoor Air, Vol. 1, pp.357-376, 1991. 
[16] ANSI/ASHRAE Standard 55-1992 An American National Standard, "Thermal environmental conditions for human occupancy," American Society of Heating, Refrigerating, and Air-Conditioning Engineers, Inc., Atlanta, 1992.

[17] ISO 7730, "Moderate thermal environments - determination of the PMV and PPD indices and specification of the conditions for thermal comfort," International Organization for Standardization, 1984.

[18] Levin, H. “Critical building design factors for IAQ,” Indoor Air, Vol. 1, pp.79-92, 1991.

[19] United States Environmental Protection Agency, "Introduction to indoor air quality - a reference manual," Report Number EPA/400/3-91/003, July 1991.

[20] Levin, H. "Protocols to improve indoor environmental quality in new construction," Proceedings of the ASHRAE Conference IAQ 87 Practical Control of Indoor Air Problems, Arlington, VA, pp.157-170, 1987.

[21] Taylor, B.N. and Kuyatt, C.E. "Guidelines for Evaluating and Expressing the Uncertainty of NIST Measurement Results," NIST Technical Note 1297, National Institute of Standards and Technology, Gaithersburg, MD, 1994.

[22] Persily, A.K. "Manual for ventilation assessment in mechanically ventilated commercial buildings," NISTIR 5329, National Institute of Standards and Technology, Gaithersburg, MD, 1994.

[23] Johnson, R., D. Heim, and L. Faiola. "The pitfalls of duplicate radon measurements," Proceedings of the 1994 International Radon Symposium, American Association of Radon Scientists and Technologists, Park Ridge, NJ, 1994.

[24] Black, M., W. Pearson, J. Brown, S. Sadie, L. Schultz, J. Peard, W. Robertson, J. Lawhon, "The state of Washington's experimental approach to controlling IAQ in new construction," Proceedings of the ASHRAE Conference IAQ 91 Healthy Buildings, Washington, D.C., pp.39-42, 1991. 


\section{ACKNOWLEDGMENTS}

The authors would like to acknowledge the Nuclear Regulatory Commission for support of this project under Interagency Agreement Number NRC-10-93-136. Special thanks goes to NRC's Office of Consolidation, especially Michael Springer, James Lundy, and Jean Bouquet. The assistance of Jim Shaffer of the Lerner Corporation in the operation of the building mechanical systems during our testing was greatly appreciated. Several colleagues and students at NIST were crucial to the collection and analysis of the data throughout the entire project, in particular Steven Emmerich and Douglas Pruitt of NIST, and cooperative education students Cherie Bulala, Huynh Luu, and Lisa Hattenburg of the University of Maryland and Kent Holguin of New Mexico State University. 

